\title{
Comparative neuropharmacological studies on three pyrrolidine-containing synthetic cathinones
}

\author{
Jakub Wojcieszak $^{1}$ (D) . Dariusz Andrzejczak ${ }^{1} \cdot$ Adam Wojtas $^{2} \cdot$ Krystyna Gołembiowska $^{2} \cdot$ Jolanta B. Zawilska $^{1}$
}

Received: 12 September 2019 / Accepted: 15 January 2020 / Published online: 1 February 2020

(c) The Author(s) 2020

\begin{abstract}
Purpose 3,4-Methylenedioxypyrovalerone (3,4-MDPV) is a prevalent member of $\alpha$-pyrrolidinophenones, a group of new psychoactive substances, known for its strong psychostimulant effect resulting from potent stimulation of dopamine (DA) circuitry in the brain. As 3,4-MDPV and its derivatives are successively being scheduled, each year novel analogs appear on the market. This study aimed at examination and direct comparison of psychostimulant properties of structural isomer of 3,4-MDPV, namely 2,3-MDPV along with a model $\alpha$-pyrrolidinophenone, pyrovalerone.

Methods Open field spontaneous locomotor activity of mice was assessed as a measure of psychostimulant potency. To evaluate the in vivo pharmacological properties of the drugs, extracellular levels of DA and serotonin (5-HT) in the mouse striatum were measured using an in vivo microdialysis technique followed by high-performance liquid chromatography with electrochemical detection. Involvement of dopaminergic system in the behavioral effects of the tested $\alpha$-pyrrolidinophenones was examined by pre-treatment with a selective $\mathrm{D}_{1}$-DA receptor antagonist, $\mathrm{SCH} 23390$, before measurement of locomotor activity in response to the drugs.

Results 3,4-MDPV, 2,3-MDPV and pyrovalerone produced time- and dose-dependent stimulation of locomotor activity, with 3,4-MDPV being more potent than the other two compounds. Observed locomotor stimulation was mediated by elevated DA-ergic neurotransmission, as all compounds caused a significant increase of extracellular DA levels in the striatum, with 3,4-MDPV being the most potent, and psychostimulant effects were abolished by SCH 23390. Interestingly, the tested pyrovalerones caused in vivo elevation of extracellular 5-HT levels, which contrasted with their in vitro pharmacologic properties. Conclusions Pyrovalerone, 2,3-MDPV and 3,4-MDPV produced psychostimulant effects mediated by stimulation of dopaminergic neurotransmission. Additionally, all tested compounds elevated extracellular levels of 5-HT in vivo.
\end{abstract}

Keywords 3,4-MDPV $\cdot$ 2,3-MDPV $\cdot$ Pyrovalerone $\cdot$ Spontaneous locomotor activity $\cdot$ Microdialysis

\section{Introduction}

The first decade of 2000s witnessed an emergence of new psychoactive substances (NPSs), followed by a rapid increase of their prevalence and constant introduction of new compounds into the clandestine market in subsequent years. One of the major groups of NPSs, both in terms of the number of identified substances and extent of their consumption,

Jakub Wojcieszak

jakub.wojcieszak@umed.lodz.pl

1 Department of Pharmacodynamics, Medical University of Łódź, Muszyńskiego 1, 90-151, Łódź, Poland

2 Department of Pharmacology, Maj Institute of Pharmacology, Polish Academy of Sciences, Smętna 12, 31-343 Kraków, Poland are psychostimulants, among which, synthetic derivatives of a naturally occurring alkaloid cathinone are of the greatest prominence [1]. Structurally, synthetic cathinones resemble United Nation-controlled drugs of abuse, such as amphetamine, methamphetamine and 3,4-methylenedioxymethamphetamine (MDMA), and act in a similar manner, by augmenting dopaminergic, norepinephrinergic, and in some cases, serotoninergic neurotransmission [2-4].

3,4-Methylenedioxypyrovalerone (3,4-MDPV) is one of the most significant synthetic cathinones, and a precursor of the subgroup called pyrrolidinophenones (pyrovalerones), distinctive by the presence of a pyrrolidine ring in place of a primary or secondary amine [5]. At the molecular level, 3,4MDPV acts as a non-substrate blocker of dopamine (DAT) and norepinephrine (NET) transporters, with no significant affinity at serotonin transporter (SERT). The compound 
selectively inhibits the re-uptake of the two catecholamines $[3,6,7]$, resulting in potent psychostimulant, methamphetamine-like effects, devoid of an empathogenic component typical to MDMA, and a high rewarding and reinforcing potential based on the increased dopaminergic neurotransmission in the nucleus accumbens $[8,9]$.

Because of its high prevalence in human abusers, 3,4MDPV has been extensively studied in behavioral animal models, mainly utilizing rats and mice. The drug has been found to increase spontaneous locomotor activity in rats and mice, an effect involving stimulation of $\mathrm{D}_{1}$-dopamine receptors. As in a case of other psychostimulants, acute effects of 3,4-MDPV administration are dose-dependent and follow an inverted U-shaped curve, meaning that low and medium doses induce increase of locomotion, while higher doses result in suppression of locomotor activity, mainly due to the occurrence of intense stereotypies, such as licking, gnawing, grooming, sniffing and self-injurious behaviors $[6,8$, 10-24]. In line with the high ability to potentiate dopaminergic neurotransmission, 3,4-MDPV is endowed by rewarding and reinforcing properties, as it induces conditioned place preference [8, 14, 24, 25], lowers thresholds for intracranial self-stimulation $[23,26]$ and is self-administered by rodents [9-11]. Moreover, 3,4-MDPV fully substitutes for cocaine and methamphetamine in rodents trained to discriminate these drugs from saline, which confirms its reinforcing effects and points to the similarity in the mechanisms of action between 3,4-MDPV and classic psychostimulants [17]. Intermittent administration of 3,4-MDPV in rodents leads to the sensitization to its stimulant effects $[12,14,15$, 20], which is a feature related to the drugs' addictive properties [27], and can be explained by the induction of adaptational changes in dopamine (DA) neurotransmission, such as changes in the DAT activity, or changes in density of $\mathrm{D}_{1}$-and $\mathrm{D}_{2}$-DA receptors [28-30].

It is established that $S(+)-3,4-\mathrm{MDPV}$ enantiomer is a primary contributor to the action of the drug. At the molecular level, $S(+)-3,4-\mathrm{MDPV}$ inhibits DA and norepinephrine (NE) re-uptake with a greater potency than $( \pm)-3,4-\mathrm{MDPV}$ and $R(-)-3,4-M D P V . ~ S(+)-3,4-M D P V$ also exhibits more pronounced reinforcing properties than $R(-)-3,4-\mathrm{MDPV}$ or the racemate, as it substitutes for cocaine with a greater potency, and is able to lower threshold of the intracranial self-stimulation (ICSS), while $R(-)-3,4-\mathrm{MDPV}$ has no effect on the ICSS. Similarly, locomotor stimulation was observed after a treatment with $S(+)-3,4-\mathrm{MDPV}$ and with the racemate with a lower potency, but not with $R(-)-3,4-\mathrm{MDPV}[31,32]$.

To obtain new derivatives, thus circumventing legal regulations, the structure of 3,4-MDPV has been subjected to numerous modifications. Therefore, several studies have been conducted to assess the influence of various structural modifications, such as changes in the side chain length and substitution of the phenyl ring, on the potency of the drug; these experiments are typically based on in vivo behavioral measures of psychomotor stimulation, as well as in vitro assays measuring affinity for monoamine transporters and the ability to inhibit the re-uptake of neurotransmitters [2, 10, 18, 33-36]. Although several comparative studies of 3,4-MDPV and its analogs have been conducted in the field of molecular pharmacology [2, 33, 35], there is a paucity of such experimental work concerning behavioral effects. Existing behavioral studies directly compare $3,4-\mathrm{MDPV}$ to its most prominent $\alpha$-pyrrolidinophenone derivative, i.e., $\alpha$-pyrrolidinovalerophenone ( $\alpha$-PVP) or analogs obtained by a truncation of the $\alpha$-PVP side chain: $\alpha$-pyrrolidinobutiophenone $(\alpha-P B P)$ and $\alpha$-pyrrolidinopropiophenone ( $\alpha$-PPP) [10, 18, 21]. No previous study has yet compared the behavioral effects of 3,4-MDPV with those of other phenyl ring-substituted $\alpha$-pyrrolidinopentiophenones.

Despite the well-established difference in potency between 3,4-MDPV enantiomers, little is known about its positional isomer, i.e., 2,3-MDPV, in which the methylenedioxy group is moved into a different position of the phenyl ring. Therefore, the aim of this study was to assess and compare the in vivo properties of 3,4-MDPV, 2,3-MDPV along with a methyl-substituted $\alpha$-pyrrolidinopentiophenone, pyrovalerone, in C57BL/6J mice. Changes in the spontaneous locomotor activity were measured as an indicator of psychostimulant activity. The mechanism of the drugs' action was assessed by measuring changes of the extracellular levels of two major monoamine neurotransmitters: DA and serotonin (5-HT). In addition, an antagonist study was performed, in which a selective antagonist of $\mathrm{D}_{1}$-DA receptors, SCH 23390, was used to abolish locomotor stimulation induced by the tested pyrrolidinophenones.

\section{Materials and methods}

\section{Reagents}

Pyrovalerone [Pyro, 1-(4-methylphenyl)-2-(1-pyrrolidinyl)1-pentanone], 2,3-MDPV [1-(1,3-benzodioxol-4-yl)-2-(1pyrrolidinyl)-1-pentanone] and 3,4-MDPV [1-(1,3-benzodioxol-5-yl)-2-(1-pyrrolidinyl)-1-pentanone] were obtained in the form of their monohydrochloride salts from Cayman Chemical (Ann Arbor, MI, USA). Isotonic saline solution for injections $(0.9 \% \mathrm{NaCl})$ was purchased from Polska Grupa Farmaceutyczna (Łódź, Poland). $\mathrm{D}_{1}$-DA receptor antagonist SCH 23390 [SCH, 8-chloro-2,3,4,5-tetrahydro3-methyl-5R-phenyl-1H-3-benzazepin-7-ol] was purchased from Sigma-Aldrich (Poznań, Poland). Ketamine hydrochloride and xylazine were purchased from Biowet (Puławy, Poland). The chemicals used for the high-performance liquid 
chromatography (HPLC) were obtained from Merck (Warsaw, Poland).

\section{Animals}

All housing conditions and experimental procedures were performed in accordance with the European Union guidelines regarding the care and use of laboratory animals [European Communities Council Directive of September 2010 (2010/63/EU)]. In all experiments, mice between 9 and 12 weeks of age were used. The animals were housed four per cage, with an automatic 12-h light/12-h dark cycle (lights on at 6:00 a.m.) and a free access to drinking water and standard food pellets. All experiments were performed during the light phase (approximately 8:00-14:00). In all experimental procedures, each animal was used only once and was naïve to treatment with the tested drug.

\section{Locomotor activity}

Experiments were performed as previously described [36]. Briefly, spontaneous locomotor activity was measured using the Opto-Varimex Auto-Track open field locomotor activity measuring hardware (model 0271-002M, Columbus Instruments, Columbus, OH, USA) consisting of four chambers $(20.3 \times 20.3 \times 20.3 \mathrm{~cm})$, each equipped with two sets of 16 infrared beams and corresponding detectors, spaced by $1.3 \mathrm{~cm}$, located on the $X$ and $Y$ horizontal axes on each of two planes. Measurement of horizontal locomotor activity was based on the count of beam breaks on the bottom plane, while the number of beam breaks on the upper layer was used to assess vertical locomotor activity (rearing and jumping). Experimental sessions lasted for $120 \mathrm{~min}$ and were conducted in a sound-attenuated room with a dim red light (invisible for rodents) from above. For assessment of psychostimulant effects of pyrovalerone $(1,3,10 \mathrm{mg} /$ $\mathrm{kg}), 2,3-\mathrm{MDPV}(1,3,10 \mathrm{mg} / \mathrm{kg})$ and 3,4-MDPV $(0.3,1$, $3 \mathrm{mg} / \mathrm{kg}$ ), animals were divided into groups of eight randomly assigned mice each. Each compound was tested in three doses using independent groups, and compared to a shared control group. Drug solutions prepared in $0.9 \% \mathrm{NaCl}$ or $0.9 \% \mathrm{NaCl}$ solution for the control group were injected subcutaneously in a volume of $0.1 \mathrm{~mL} / 10 \mathrm{~g}$ of body mass immediately before the start of the experiment. For the study examining an involvement of $\mathrm{D}_{1}$-DA receptors in the psychostimulatory effects of the drugs, animals were divided into groups consisting of eight randomly assigned mice for drug-treated groups and of 11 randomly assigned mice for one shared control group. In this part of the study, each animal obtained one injection of the tested compound (each at $3 \mathrm{mg} / \mathrm{kg}$ ) $30 \mathrm{~min}$ after pre-treatment with either saline or SCH $23390(60 \mu \mathrm{g} / \mathrm{kg})$ and placed immediately in the apparatus. Dose of $\alpha$-pyrrolidinophenones in the antagonist study was selected based on the results from the first experiment, as $3 \mathrm{mg} / \mathrm{kg}$ was the lowest dose producing a statistically significant increase in horizontal locomotor activity for all drugs. Control group obtained two injections of saline, 30 min apart.

\section{Brain microdialysis}

Experiments were conducted as previously described [36].

\section{Surgery and microdialysis procedure}

Animals were divided into groups consisting of six or seven randomly assigned mice. Vertical microdialysis probes with a 2-mm-long active site (MAB 10.8.2.Cu; AgnTho's, Lindigö, Sweden) were implanted into the striatum using the following coordinates: $\mathrm{AP}+1.0, \mathrm{~L}+1.8, \mathrm{~V}-3.8$ [37], during ketamine $(7.5 \mathrm{mg} / \mathrm{kg})+$ xylazine $(1 \mathrm{mg} / \mathrm{kg})$ anesthesia. On the next day, probe inlets were connected to a syringe pump (BAS, West Lafayette, IN, USA) delivering artificial cerebrospinal fluid composed of $\mathrm{NaCl} 147, \mathrm{KCl} 2.7, \mathrm{MgCl}_{2}$ 1.0, $\mathrm{CaCl}_{2} 1.2(\mathrm{mM}), \mathrm{pH} 7.4$, at a flow rate of $1.5 \mu \mathrm{L} / \mathrm{min}$. After $1 \mathrm{~h}$ of washout, three basal dialysate samples were collected every $20 \mathrm{~min}$. Subsequently, animals were subjected to injection of pyrovalerone $(3 \mathrm{mg} / \mathrm{kg}, 10 \mathrm{mg} / \mathrm{kg}$ ), 2,3-MDPV (3 mg/kg, $10 \mathrm{mg} / \mathrm{kg}$ ) or 3,4-MDPV (3 mg/kg, $10 \mathrm{mg} / \mathrm{kg}$ ) and $0.9 \% \mathrm{NaCl}$ solution for the control group and collection of samples was continued for $180 \mathrm{~min}$. After completion of dialysate collection, animals were sacrificed by cervical dislocation and their brains were isolated for histological verification of accuracy of the probe placement.

\section{Analytical procedure of samples}

DA and 5-HT contents in the dialysate fractions were analyzed by HPLC with electrochemical detection. Chromatography was performed using an Ultimate 3000 System (Dionex, Sunnyvale, CA, USA), a Coulochem III electrochemical detector (model 5300; ESA, Chelmsford, MA, USA) with a 5020 guard cell, a 5014B microdialysis cell and a Hypersil Gold-C18 analytical column $(3 \times 100 \mathrm{~mm}$; Thermo Scientific, Waltham, MA, USA). The mobile phase was composed of $0.1 \mathrm{M}$ potassium phosphate buffer adjusted to $\mathrm{pH}$ 3.6, $0.5 \mathrm{mM}$ EDTA, $16 \mathrm{mg} / \mathrm{L}$ 1-octanesulfonic acid sodium salt and $2 \%$ methanol. The flow rate during analysis was set at $0.7 \mathrm{~mL} / \mathrm{min}$. The applied potential of a guard cell was $+600 \mathrm{mV}$, while those of the microdialysis cells were $\mathrm{E} 1=-50 \mathrm{mV}$ and $\mathrm{E} 2=+300 \mathrm{mV}$ with a sensitivity set at $50 \mathrm{nA} / \mathrm{V}$. The chromatographic data were processed by Chromeleon v. 6.80 (Dionex) software, run on a personal computer. 
Pyrovalerone

Distance
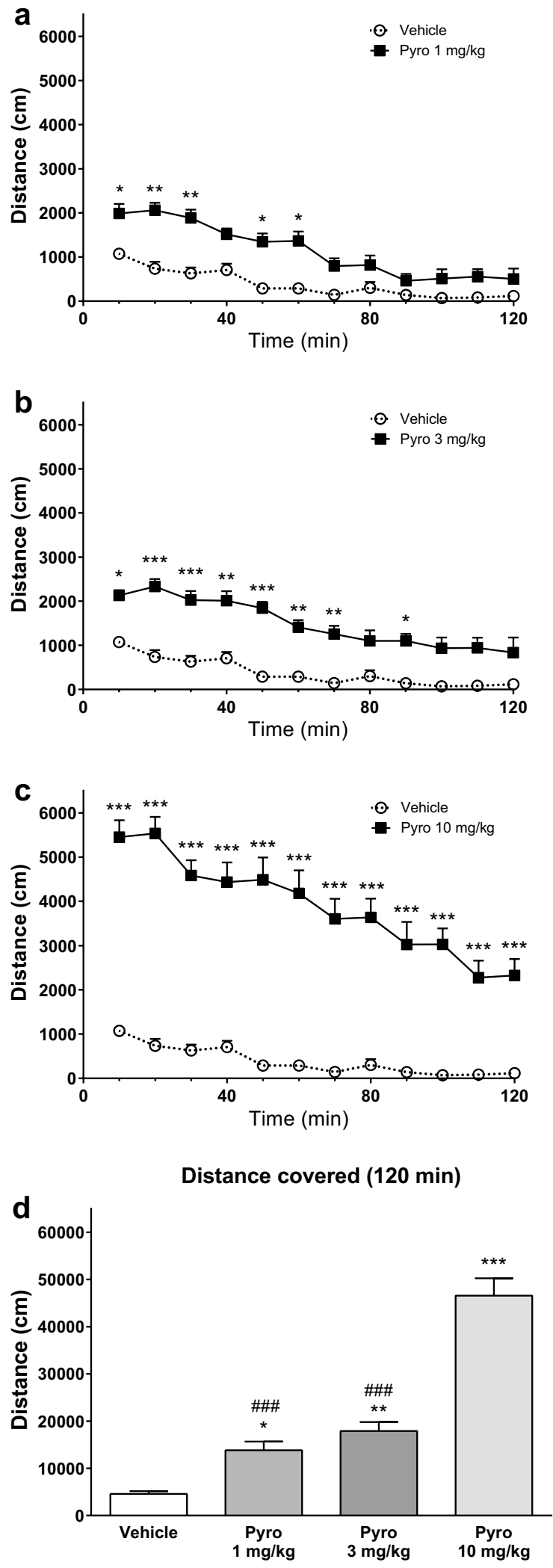

Rearing
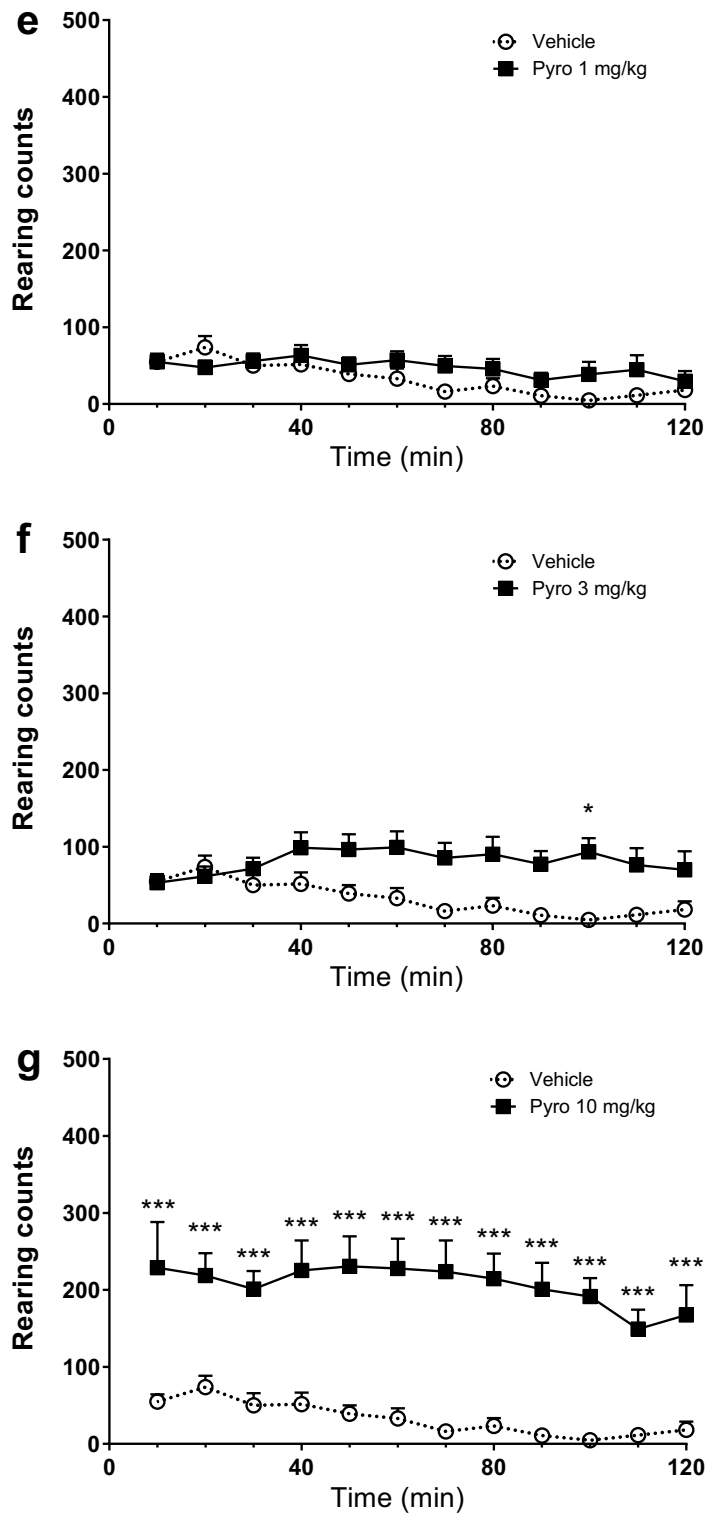

Rearing (120 min)

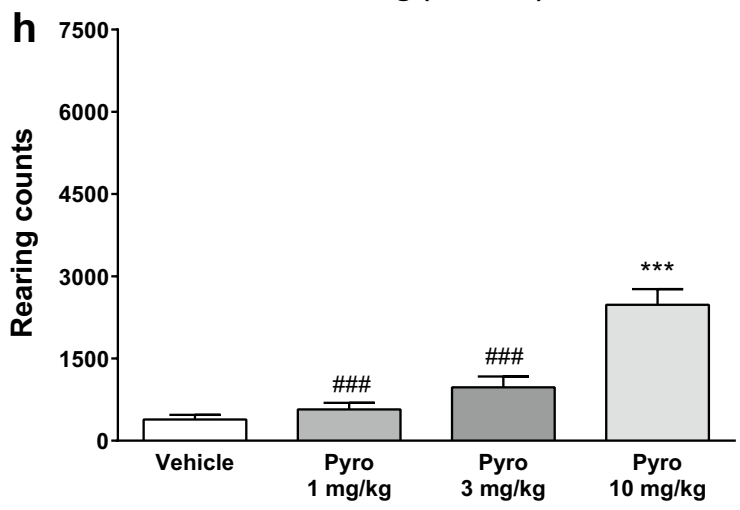


4Fig. 1 Spontaneous locomotor activity of mice after treatment with pyrovalerone (Pyro; 1, 3, $10 \mathrm{mg} / \mathrm{kg}$ ). Average horizontal (a-c) and vertical $(\mathbf{e}-\mathbf{g})$ activities in 10-min bins. $\mathbf{d}$ Total distance traveled during $120 \mathrm{~min}$. h Total rearing counts during $120 \mathrm{~min}$. Data presented as mean \pm standard error of the mean (SEM) $(n=8)$. $* * * p<0.001$;

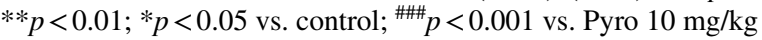

\section{Data analysis}

Statistical analysis was performed using GraphPad Prism 6.0 software (GraphPad, San Diego, CA, USA). Locomotor activity was expressed as the distance traveled $(\mathrm{cm})$ and the number of rearings within 10-min time bins. DA and 5-HT levels are expressed as percent of the basal level assumed as $100 \%$ within 20-min time bins. For time-response curves, statistical significance was determined using a two-way repeated-measures analysis of variance (treatment, time after injection), followed by Tukey's post hoc test. Additionally, total effects, expressed as the total distance covered and the total number of rearings during $120 \mathrm{~min}$ of locomotor activity assessment and the area under the curve (AUC) after $180 \mathrm{~min}$ for extracellular monoamine levels were analyzed using one-way ANOVA followed by Tukey's post hoc test. Results were considered statistically significant when $p<0.05$.

\section{Results}

\section{Spontaneous locomotor activities}

Pyrovalerone, 3,4-MDPV and 2,3-MDPV caused significant dose- and time-dependent increase of both horizontal and vertical spontaneous locomotor activities in mice (Figs. 1, $2,3)$.

After treatment with pyrovalerone, spontaneous horizontal locomotor activity was significantly affected by treatment $[F(3,28)=63.2 ; p<0.0001]$, time $[F(11,308)=44$; $p<0.0001]$ and interaction between treatment and time $[F(33,308)=3.68 ; p<0.0001]$. Significant elevation of locomotor activity against control group was observed 0-30 and 40-60 min post-injection ( $1 \mathrm{mg} / \mathrm{kg})$; $0-70$ and $80-90 \mathrm{~min}$ post-injection $(3 \mathrm{mg} / \mathrm{kg})$, and in every $10-\mathrm{min}$ bin through $120 \mathrm{~min}$ from the beginning after the highest dose of $10 \mathrm{mg} / \mathrm{kg}$. All doses of pyrovalerone significantly elevated the total distance covered during $120 \mathrm{~min}$; the effects of the $10 \mathrm{mg} / \mathrm{kg}$ dose were significantly stronger compared to both $1 \mathrm{mg} / \mathrm{kg}$ and $3 \mathrm{mg} / \mathrm{kg}$. Vertical locomotor activity was significantly affected by treatment $[F(3,28)=25.4 ; p<0.0001]$ and time $[F(11,308)=2.51 ; p=0.0049]$, but not the interaction between treatment and time $[F(33,308)=0.992$; $p=0.4845]$. The groups treated with $3 \mathrm{mg} / \mathrm{kg}$ (90-100 $\mathrm{min}$ post-injection) and $10 \mathrm{mg} / \mathrm{kg}(0-120 \mathrm{~min}$ post-injection) of pyrovalerone demonstrated a significantly higher rearing behavior count than the control group. The total number of rearings during 120 min was significantly elevated only after treatment with the highest tested dose $(10 \mathrm{mg} / \mathrm{kg})$ of pyrovalerone. The groups treated with $1 \mathrm{mg} / \mathrm{kg}$ and $3 \mathrm{mg} / \mathrm{kg}$ of pyrovalerone also displayed significantly lower vertical locomotor activity than the $10 \mathrm{mg} / \mathrm{kg}$ group (Fig. 1).

Two-way ANOVA revealed that in groups of mice treated with 3,4-MDPV, horizontal locomotor activity was significantly influenced by treatment $[F(3,28)=20.9 ; p<0.0001]$, time $[F(11,308)=20.7 ; p<0.0001]$ and interaction between treatment and time $[F(33,308)=5.28 ; p<0.0001]$. The lowest dose of $3,4-\mathrm{MDPV}(0.3 \mathrm{mg} / \mathrm{kg})$ caused elevation of locomotor activity only during 40-50 min post-injection. However, the effects of higher doses were of a markedly longer duration: locomotor activity of mice was significantly increased during 10-120 min period after $1 \mathrm{mg} / \mathrm{kg}$ and through the entire session (0-120 min) after $3 \mathrm{mg} / \mathrm{kg}$. The total distance traveled during $120 \mathrm{~min}$ was significantly higher in 1 and $3 \mathrm{mg} / \mathrm{kg}$ groups compared to both the control and $0.3 \mathrm{mg} / \mathrm{kg}$ group. Vertical locomotor activity after administration of 3,4-MDPV was significantly affected by treatment $[F(3,28)=5.00 ; p=0.0067]$ and interaction between treatment and time $[F(33,308)=2.20 ; p=0.0003]$, but not by time itself $[F(11,308)=1.53 ; p=0.1182]$. The groups treated with 3,4-MDPV at $1 \mathrm{mg} / \mathrm{kg}(60-70$ and 90-100 min post-injection) and $3 \mathrm{mg} / \mathrm{kg}(10-20$ and 50-120 min post-injection) demonstrated significantly greater rearings than the control group. The total count of the rearing behavior vs. the control group was significantly increased only after $3 \mathrm{mg} / \mathrm{kg}$ dose of 3,4-MDPV and there were no significant differences between groups treated with various doses of 3,4-MDPV (Fig. 2).

In mice treated with 2,3-MDPV, spontaneous horizontal locomotor activity was significantly affected by treatment $[F(3,28)=23.0 ; p<0.0001]$ and time $[F(11,308)=22.9$; $p<0.0001]$, but not interaction between treatment and time $[F(33,308)=1.25 ; p=0.172]$. After treatment with $3 \mathrm{mg} /$ $\mathrm{kg}$ of 2,3-MDPV horizontal locomotor activity was significantly elevated during the 0-90 min post-injection period, while treatment with $10 \mathrm{mg} / \mathrm{kg}$ caused a significant increase observed in every 10-min bin during the full $120 \mathrm{~min}$ of the experimental session. The significantly greater distance was covered during $120 \mathrm{~min}$ after treatment with $3 \mathrm{mg} / \mathrm{kg}$ and $10 \mathrm{mg} / \mathrm{kg}$ of 2,3-MDPV compared to controls. The highest dose, i.e., $10 \mathrm{mg} / \mathrm{kg}$, produced effects significantly stronger than $1 \mathrm{mg} / \mathrm{kg}$ and $3 \mathrm{mg} / \mathrm{kg}$. 2,3-MDPV also produced marked effects on vertical locomotor activity with treatment $[F(3$, $28)=10.6 ; p<0.0001]$ and interaction between treatment and time $[F(33,308)=2.02 ; p=0.0012]$ being significant factors, but not time itself $[F(11,308)=1.51 ; p=0.127]$. 2,3-MDPV did not cause a significant increase of the rearing behavior in any $10-\mathrm{min}$ time bin at $1 \mathrm{mg} / \mathrm{kg}$ and $3 \mathrm{mg} / \mathrm{kg}$, 


\section{3,4-MDPV}

Distance
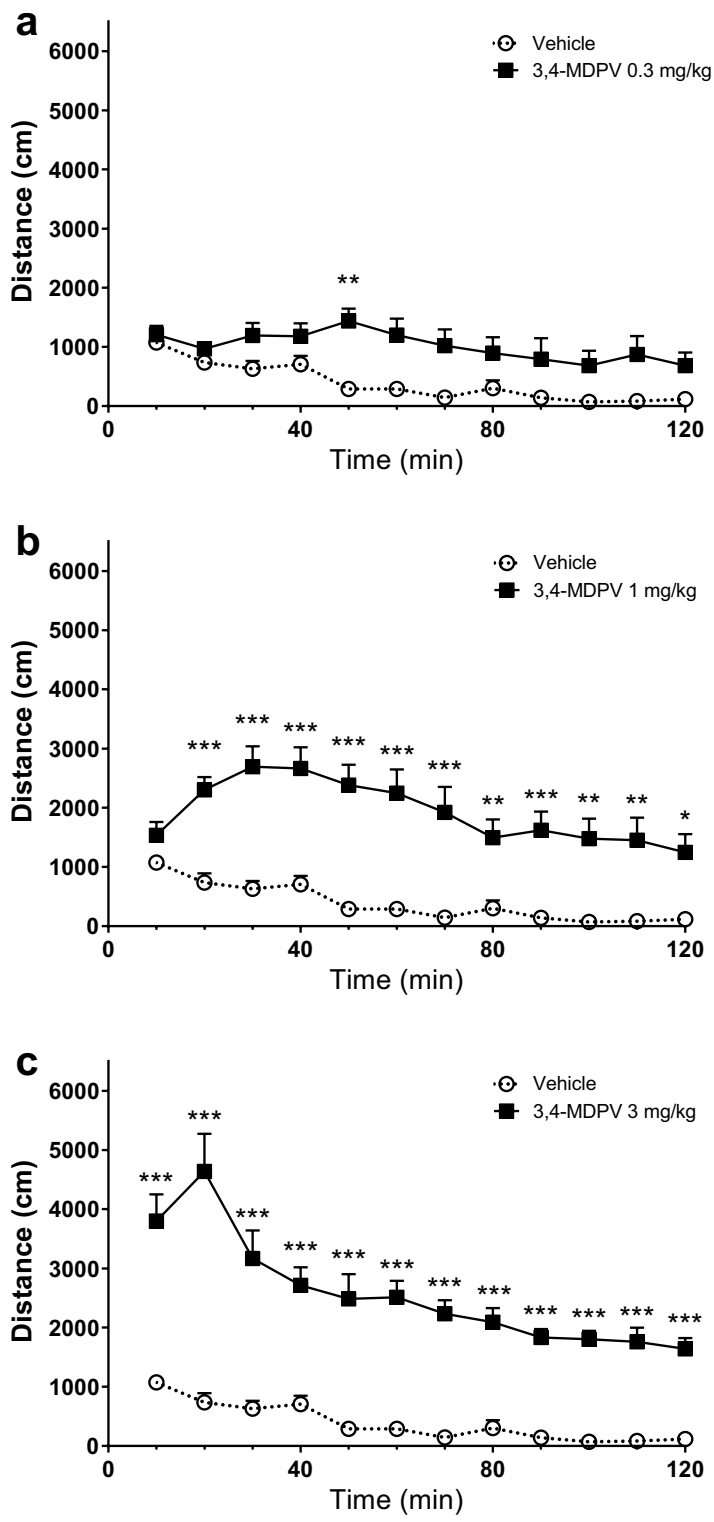

Distance covered (120 min)

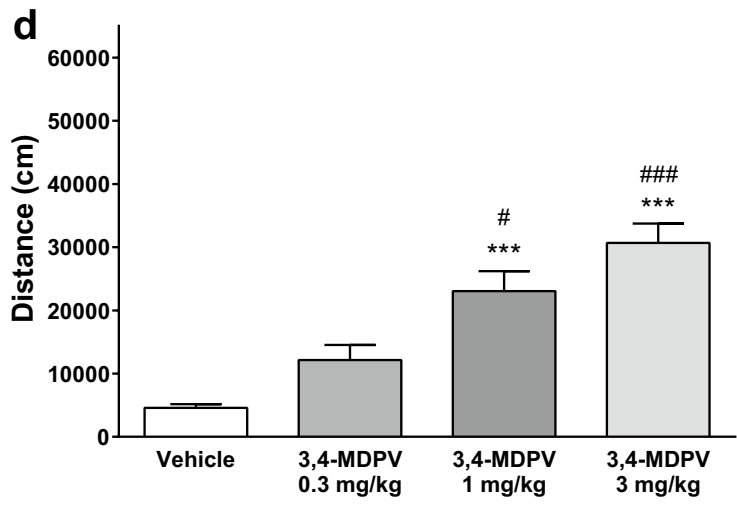

Rearing
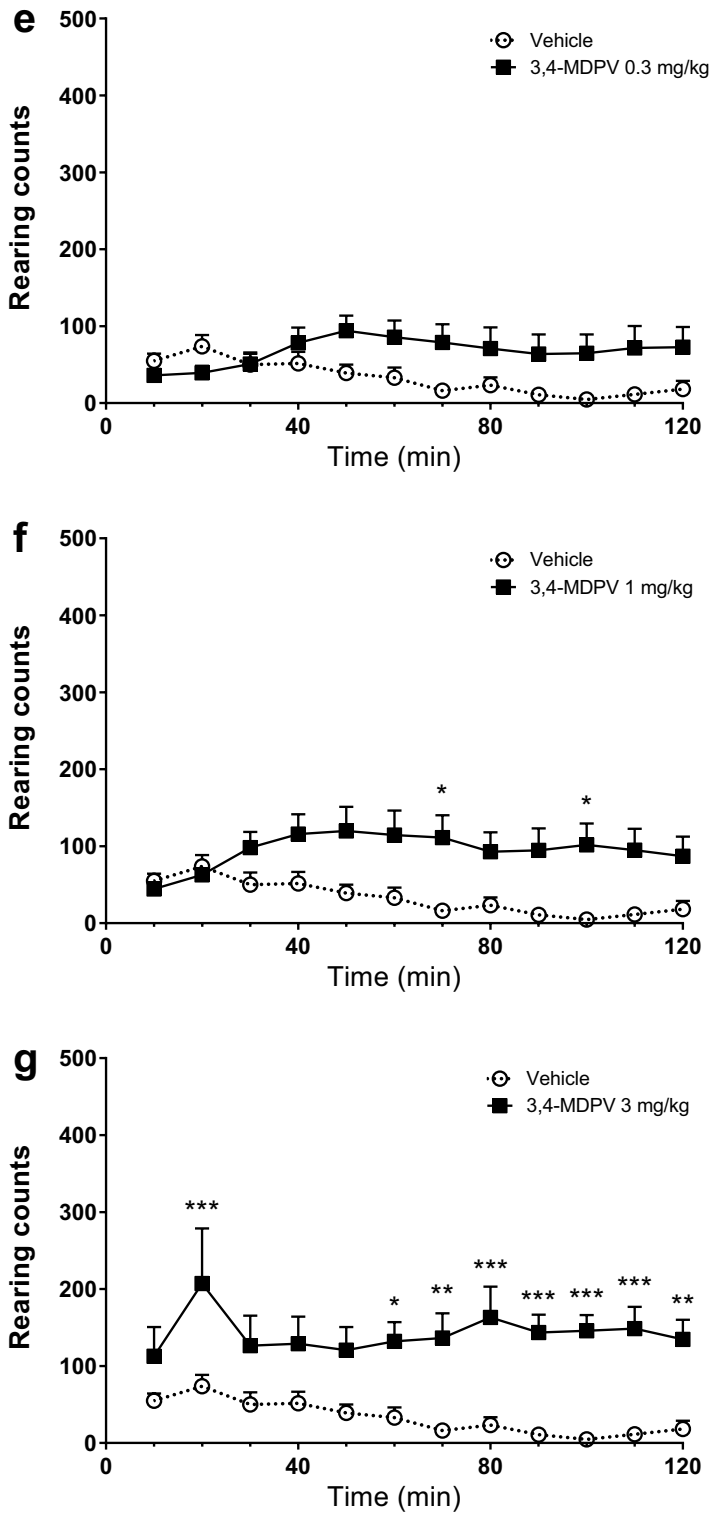

Rearing (120 min)

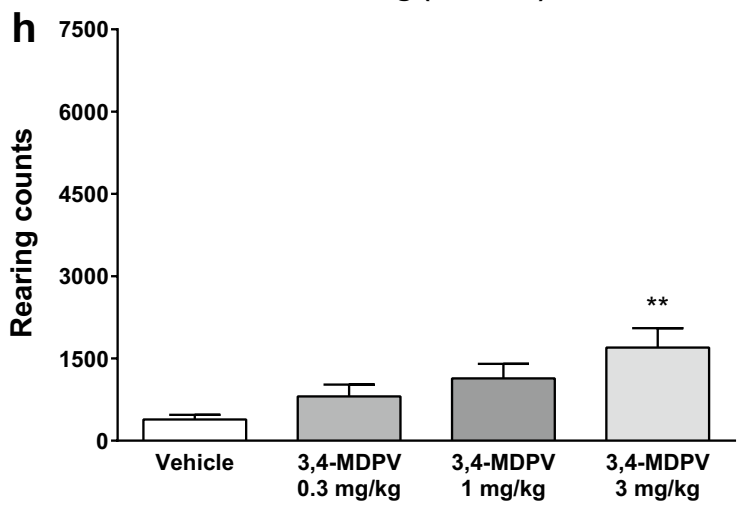


4Fig. 2 Spontaneous locomotor activity of mice after treatment with 3,4-MDPV $(0.3,1,3 \mathrm{mg} / \mathrm{kg})$. Average horizontal (a-c) and vertical $(\mathbf{e}-\mathbf{g})$ activities in 10-min bins. $\mathbf{d}$ Total distance traveled during $120 \mathrm{~min}$. h Total rearing counts during $120 \mathrm{~min}$. Data presented as mean \pm standard error of the mean (SEM) $(n=8)$. *** $p<0.001$;

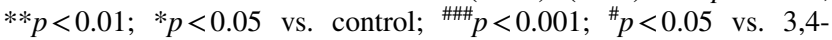
MDPV $0.3 \mathrm{mg} / \mathrm{kg}$

while at $10 \mathrm{mg} / \mathrm{kg}$ the difference was statistically significant in every time bin during $120 \mathrm{~min}$. Also the total number of rearings during the full experiment was significantly higher compared to the control group only after treatment with $10 \mathrm{mg} / \mathrm{kg}$, and the rearing behavior was significantly more pronounced in the $10 \mathrm{mg} / \mathrm{kg}$ group compared to two lower doses (Fig. 3).

\section{Effects of blockade of $D_{1}-D A$ receptors on the action of pyrovalerone, 3,4-MDPV and 2,3-MDPV on the spontaneous locomotor activity of mice}

Pre-treatment with $\mathrm{SCH} 23390$, a selective $\mathrm{D}_{1}$-DA receptor antagonist, $30 \mathrm{~min}$ before treatment with either of the tested $\alpha$-pyrrolidinophenones resulted in the entire abolition of any drug-induced increase of horizontal spontaneous locomotor activity in mice (Fig. 4).

In groups treated with pyrovalerone $(3 \mathrm{mg} / \mathrm{kg})$ after pretreatment with either saline or SCH $23390(0.06 \mathrm{mg} / \mathrm{kg})$, spontaneous horizontal locomotor activity was affected by treatment $[F(2,24)=23.2 ; p<0.0001]$, time $[F(11$, $264)=23.1 ; p<0.0001]$, and interaction between treatment and time $[F(22,264)=8.13 ; p<0.0001]$. The distance traveled by mice pre-treated with SCH 23390 was never significantly higher compared to controls. In fact, it was significantly lower than in mice treated with saline and pyrovalerone through the entire period of pyrovaleroneinduced hyperactivity (0-80 min post-injection). The total distance traveled by mice pre-treated with SCH 23390 during 120 min was not significantly higher compared to the control animals. On the other hand, it was significantly lower than that covered by mice treated with pyrovalerone after saline pre-treatment (Fig. 4a, b).

When mice received 3,4-MDPV (3 $\mathrm{mg} / \mathrm{kg})$ after pre-treatment with either saline or SCH $23390(0.06 \mathrm{mg} / \mathrm{kg})$ horizontal locomotor activity was significantly affected by treatment $[F(2,24)=17.6 ; p<0.0001]$, time $[F(11,264)=24.8$; $p<0.0001]$ and interaction between treatment and time $[F(22,264)=4.98 ; p<0.0001]$. The distance covered by SCH 23390 pre-treated animals was significantly lower than in mice injected with saline and 3,4-MDPV for the major part of 3,4-MDPV action (0-100 min post-injection period). The total distance traveled during 120 min was significantly lower in mice treated with SCH 23390 and 3,4-MDPV compared to saline and 3,4-MDPV group, but there was no difference against the control group (Fig. 4c, d).
In mice treated with either saline or SCH $23390(0.06 \mathrm{mg} /$ $\mathrm{kg}$ ), followed by the administration of 2,3-MDPV (3 mg/ $\mathrm{kg}$ ), horizontal locomotor activity was significantly affected by treatment $[F(2,24)=13.6 ; p=0.0001]$ and time $[F(11$, $264)=16.6 ; p<0.0001]$, but not interaction between treatment and time $[F(22,264)=1.30 ; p=0.170]$. The distance traveled by mice treated with SCH 23390 and 2,3-MDPV was significantly lower than in the group treated with saline and 2,3-MDPV during the entire period of 2,3-MDPVinduced hyperactivity (0-90 and 100-110 min post-injection). The total distance traveled by mice treated with saline and 2,3-MDPV was significantly higher compared to the control and SCH 23390 and 2,3-MDPV groups, between which there was no significant difference (Fig. 4e, f).

\section{Extracellular levels of DA and 5-HT in the mouse striatum}

Basal levels of extracellular monoamine levels obtained from all mice subjected to the procedure were (mean $\pm \mathrm{SEM})$ : DA, $5.21 \pm 0.49 \mathrm{pg} / 10 \mu \mathrm{L}(\mathrm{n}=44) ; 5-\mathrm{HT}, 0.91 \pm 0.081 \mathrm{pg} / 10 \mu \mathrm{L}$ $(n=45)$.

Treatment with pyrovalerone at doses of 3 and $10 \mathrm{mg} /$ $\mathrm{kg}$ resulted in a significant increase of extracellular DA level in the mouse striatum with treatment $[F(2,15)=83.2$; $p<0.0001]$, time $[F(8,120)=135 ; p<0.0001]$ and interaction between treatment and time being significant factors $[F(16,120)=50.7 ; p<0.0001]$. At $3 \mathrm{mg} / \mathrm{kg}$, the effect lasted for $60 \mathrm{~min}$, with a maximal effect of approximately $280 \%$ of the basal level 20 min post-injection. Elevated extracellular levels of DA were detected after treatment with $10 \mathrm{mg} / \mathrm{kg}$ of pyrovalerone during $80 \mathrm{~min}$, with a maximal effect of approximately $640 \%$ of the basal level $20 \mathrm{~min}$ post-injection. Additionally, extracellular levels of DA in the 80 min period after treatment were higher in the group treated with $10 \mathrm{mg} / \mathrm{kg}$ of pyrovalerone than those treated with $3 \mathrm{mg} / \mathrm{kg}$ (Fig. 5a). Extracellular 5-HT levels in the striata of mice treated with pyrovalerone were significantly affected by treatment $[F(2,15)=552 ; p<0.0001]$, time $[F(8$, $120)=16.9 ; p<0.0001]$ and interaction between treatment and time $[F(16,120)=8.72 ; p<0.0001]$. Treatment with $3 \mathrm{mg} / \mathrm{kg}$ pyrovalerone produced a slight increase of extracellular 5-HT level (approximately $140 \%$ of the basal level) observed only at one time point ( $80 \mathrm{~min}$ post-injection). In contrast, a higher pyrovalerone dose, $10 \mathrm{mg} / \mathrm{kg}$, induced a pronounced increase of extracellular 5-HT levels, with a maximal effect of approximately $280 \%$ of the basal level, observed 60 min post-injection. Extracellular 5-HT levels were found to be significantly higher than those of control animals and mice treated with the lower dose $(3 \mathrm{mg} / \mathrm{kg})$ at every time point during the full $180 \mathrm{~min}$ of the experimental session (Fig. 5b). Additionally, analysis of the total effects of 


\section{2,3-MDPV}

Distance
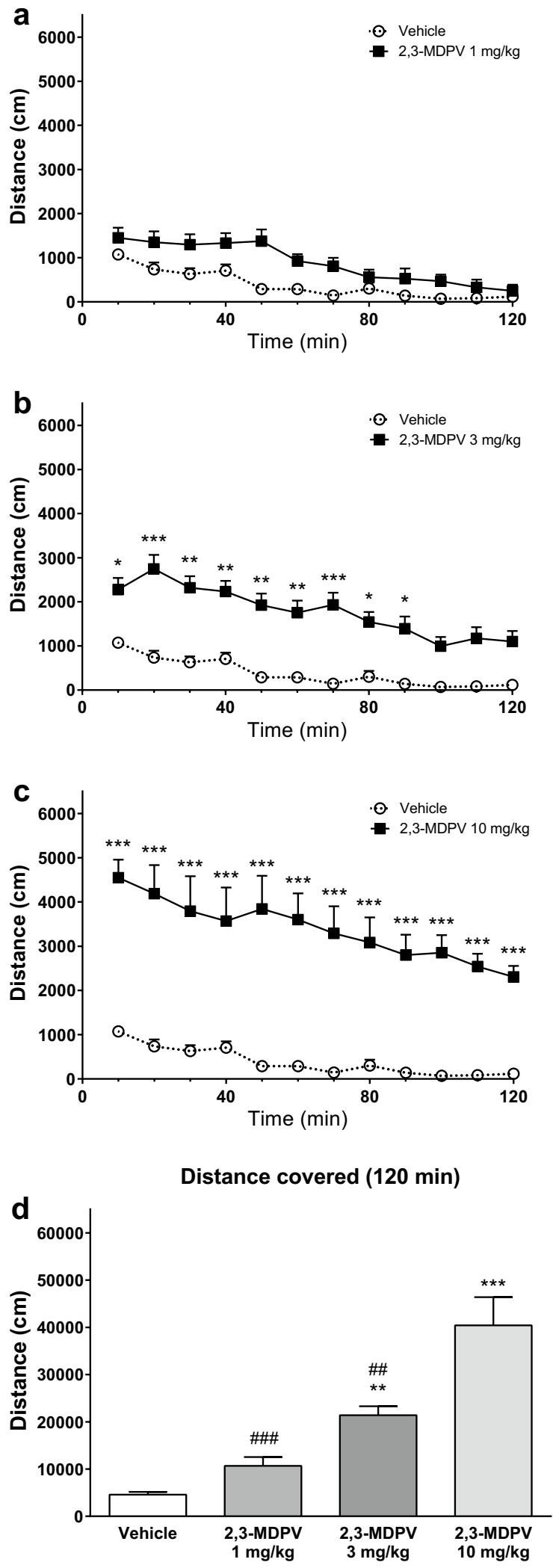

Rearing
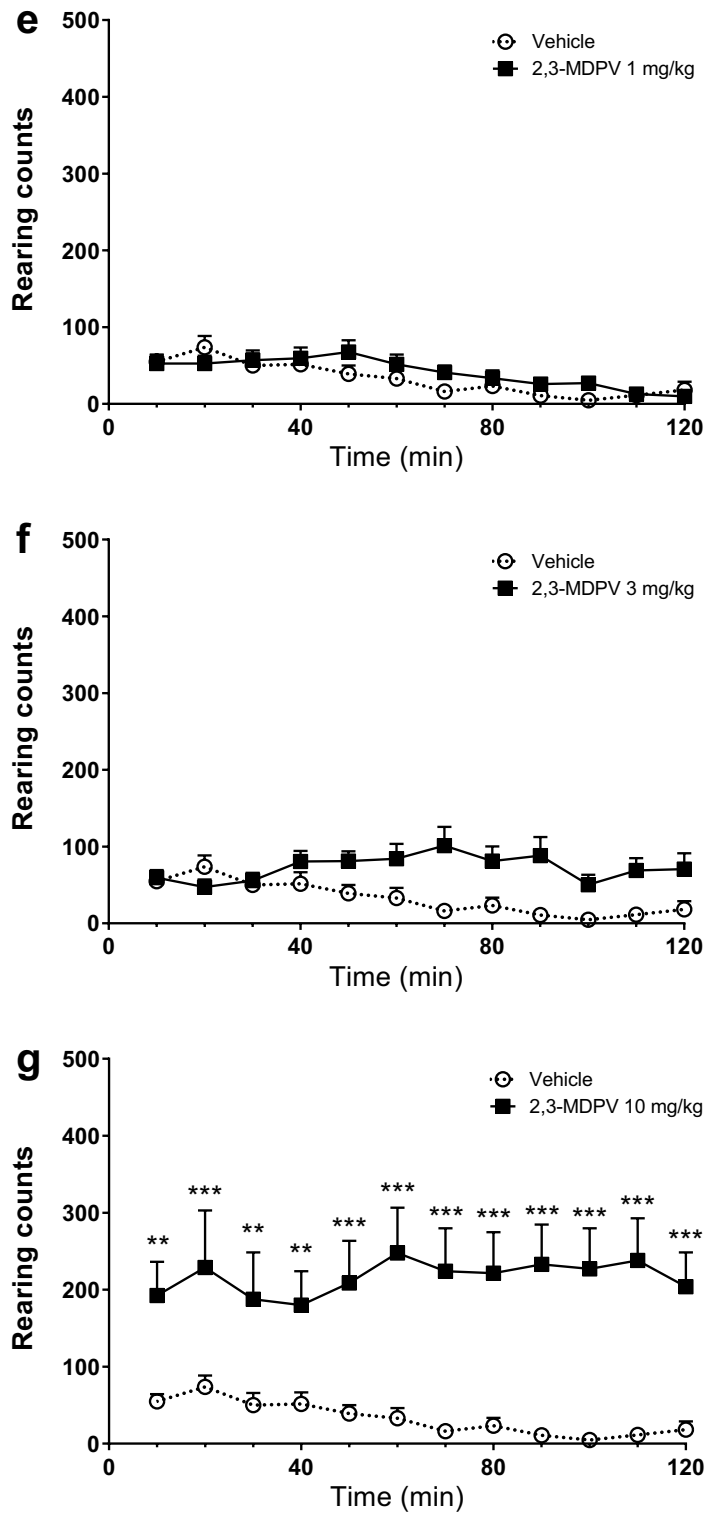

Rearing (120 min)

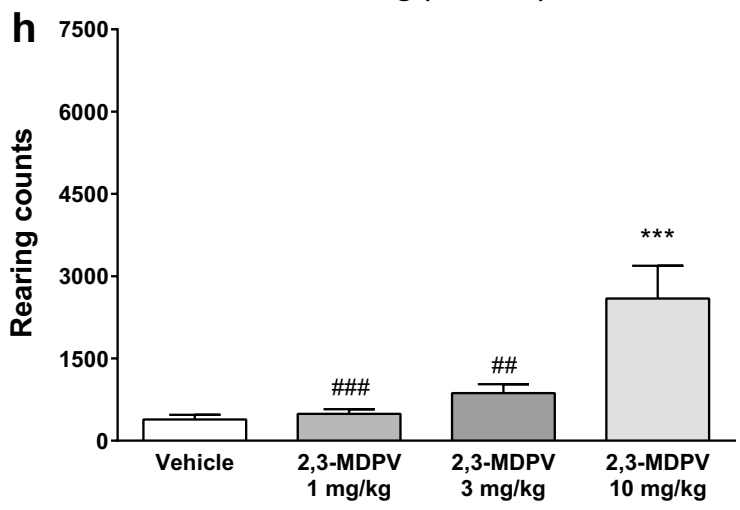


4Fig. 3 Spontaneous locomotor activity of mice after treatment with 2,3-MDPV $(1,3,10 \mathrm{mg} / \mathrm{kg})$. Average horizontal (a-c) and vertical (e-g) activities in 10-min bins. d Total distance traveled during $120 \mathrm{~min}$. h Total rearing counts during $120 \mathrm{~min}$. Data presented as mean \pm standard error of the mean (SEM) $(n=8)$. *** $p<0.001$; $* * p<0.01 ; * p<0.05$ vs. control; ${ }^{* \# \#} p<0.001 ;{ }^{\# \#} p<0.01$ vs. 2,3MDPV $10 \mathrm{mg} / \mathrm{kg}$

pyrovalerone measured as the area under the curve (AUC) revealed that extracellular levels of both DA and 5-HT were significantly increased compared to controls only after the dose of $10 \mathrm{mg} / \mathrm{kg}$, and significant differences in extracellular levels of both monoamines were observed between groups treated with different doses of pyrovalerone (Fig. $5 \mathrm{~g}, \mathrm{~h}$ ).

Following treatment with 3,4-MDPV at doses of 3 and $10 \mathrm{mg} / \mathrm{kg}$, extracellular levels of DA in the mouse striatum were significantly affected by treatment $[F(2,17)=555$; $p<0.0001]$, time $[F(8,136)=93.2 ; p<0.0001]$ and interaction between treatment and time $[F(16,136)=40.0$; $p<0.0001$ ]. 3,4-MDPV at the dose of $3 \mathrm{mg} / \mathrm{kg}$ produced a marked increase of extracellular DA levels, observed during 160 min post-injection, with a maximal effect of approximately $260 \%$ of the basal level 40 min post-injection. The higher dose $(10 \mathrm{mg} / \mathrm{kg})$ of 3,4-MDPV evoked an even stronger effect on extracellular DA levels, which was found to be elevated during the full 180 min of the experiment, reaching a maximal effect of approximately $540 \%$ of the basal level at 40 min post-injection. Noteworthy, extracellular levels of DA were significantly higher in $10 \mathrm{mg} / \mathrm{kg}$ group compared to $3 \mathrm{mg} / \mathrm{kg}$ group for the entire 180-min period (Fig. 5c). Similarly, after treatment with 3,4-MDPV at $3 \mathrm{mg} /$ $\mathrm{kg}$ and $10 \mathrm{mg} / \mathrm{kg}$ extracellular levels of 5-HT were significantly affected by treatment $[F(2,17)=1152 ; p<0.0001]$, time $[F(8,136)=85.5 ; p<0.0001]$ and interaction between treatment and time $[F(16,136)=40.6 ; p<0.0001]$. Both doses of 3,4-MDPV produced a significant increase of extracellular 5-HT levels in the mouse striatum observed for $180 \mathrm{~min}$. Also, during the full $180 \mathrm{~min}$ of the experiment, 5-HT levels were significantly higher in the group treated with 3,4-MDPV at the dose of $10 \mathrm{mg} / \mathrm{kg}$ compared to $3 \mathrm{mg} / \mathrm{kg}$. Maximal effects were approximately $210 \%$ of the basal level observed at 60 min post-injection for $3 \mathrm{mg} /$ $\mathrm{kg}$ and approximately $380 \%$ of the basal level at $40 \mathrm{~min}$ post-injection for $10 \mathrm{mg} / \mathrm{kg}$ (Fig. 5d). Additionally, analysis of the total effects of 3,4-MDPV measured as the AUC revealed that extracellular levels of both DA and 5-HT were significantly increased compared to the control group after treatment with 3,4-MDPV at both $3 \mathrm{mg} / \mathrm{kg}$ and $10 \mathrm{mg} / \mathrm{kg}$. Moreover, extracellular levels of both monoamines were significantly higher in mice treated with the dose of $10 \mathrm{mg} / \mathrm{kg}$ compared to $3 \mathrm{mg} / \mathrm{kg}$ (Fig. $5 \mathrm{~g}$, h).

After treatment with 2,3-MDPV at $3 \mathrm{mg} / \mathrm{kg}$ and $10 \mathrm{mg} /$ $\mathrm{kg}$, extracellular levels of DA were significantly affected by treatment $[F(2,15)=178 ; p<0.0001]$, time $[F(8$,
$120)=79.9 ; p<0.0001]$ and interaction between treatment and time $[F(16,120)=27.3 ; p<0.0001]$. In animals treated with $3 \mathrm{mg} / \mathrm{kg}$ of 2,3-MDPV, extracellular levels of DA were significantly elevated during 140 min post-injection, with a maximal effect of approximately $340 \%$ of the basal level at $40 \mathrm{~min}$ post-injection. In animals treated with $10 \mathrm{mg} /$ $\mathrm{kg}$ of 2,3-MDPV, extracellular levels of DA were significantly elevated also for $140 \mathrm{~min}$ compared to the control group, but they were also significantly higher than those observed in mice treated with $3 \mathrm{mg} / \mathrm{kg}$ during the first $60 \mathrm{~min}$ of the experiment. A maximal effect of 2,3-MDPV at $10 \mathrm{mg} / \mathrm{kg}$ reached approximately $510 \%$ of the basal level and was observed at 40 min post-injection (Fig. 5e). Extracellular levels of 5-HT after treatment with 2,3-MDPV at $3 \mathrm{mg} / \mathrm{kg}$ and $10 \mathrm{mg} / \mathrm{kg}$ were significantly affected by treatment $[F(2,16)=532 ; p<0.0001]$, time $[F(8,128)=32.8$; $p<0.0001]$ and interaction between treatment and time $[F(16,128)=8.71 ; p<0.0001]$. In animals treated with $3 \mathrm{mg} / \mathrm{kg}$ of 2,3-MDPV, extracellular levels of 5-HT were significantly elevated for $160 \mathrm{~min}$ post-injection, reaching a maximal effect of approximately $240 \%$ of the basal level at 100 min post-injection. In animals treated with $10 \mathrm{mg} /$ $\mathrm{kg}$ of 2,3-MDPV, extracellular levels of 5-HT were significantly increased compared to the control group for $180 \mathrm{~min}$ post-injection, reaching a maximal effect of approximately $380 \%$ of the basal level at 100 min post-injection. Moreover, extracellular levels of 5-HT were significantly higher in the group treated with $10 \mathrm{mg} / \mathrm{kg}$ of 2,3-MDPV than those treated with $3 \mathrm{mg} / \mathrm{kg}$ during the whole 180-min experimental session (Fig. 5f). Additionally, analysis of the total effects of 2,3-MDPV measured as the AUC revealed that extracellular levels of both monoamines were significantly higher than in controls after treatment with both doses $(3 \mathrm{mg} / \mathrm{kg}$ and $10 \mathrm{mg} / \mathrm{kg}$ ). Moreover, extracellular levels of both DA and 5-HT were significantly higher in mice treated with the high dose of 2,3-MDPV (10 mg/kg) compared to the low dose (3 mg/kg) (Fig. 5g, h).

\section{Discussion}

The current study demonstrates that 2,3-MDPV, the positional isomer of 3,4-MDPV, evokes locomotor stimulation similar to the parent compound, but with a lower potency. Comparison of locomotor effects after administration of 3,4MDPV, 2,3-MDPV and pyrovalerone at $3 \mathrm{mg} / \mathrm{kg}$ showed that the increase of horizontal locomotor activity, presented as the total distance covered during $120 \mathrm{~min}$, was significantly less pronounced after 2,3-MDPV compared to 3,4-MDPV. The magnitude of 2,3-MDPV action did not markedly differ from that of pyrovalerone (Fig. 6a). Furthermore, only 3,4MDPV used at $3 \mathrm{mg} / \mathrm{kg}$ elevated vertical locomotor activity (rearing) during the entire $120 \mathrm{~min}$ of analysis, which 


\section{Distance}

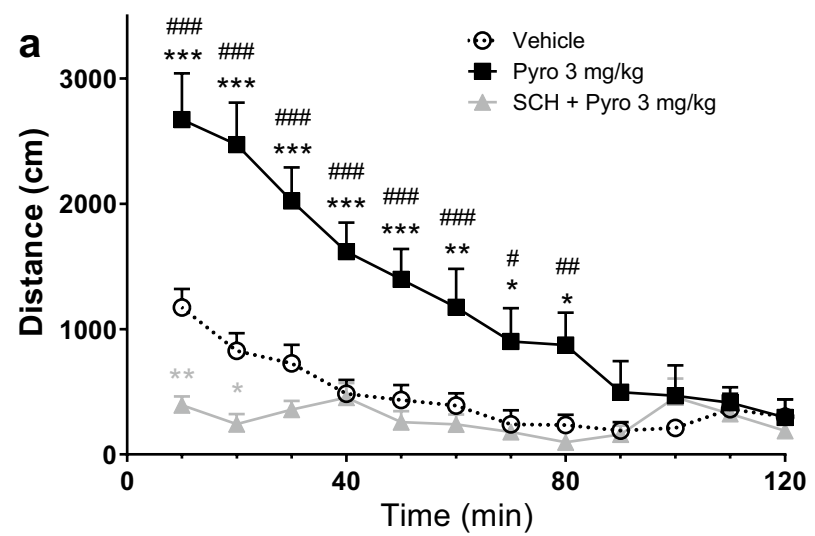

\section{Distance}

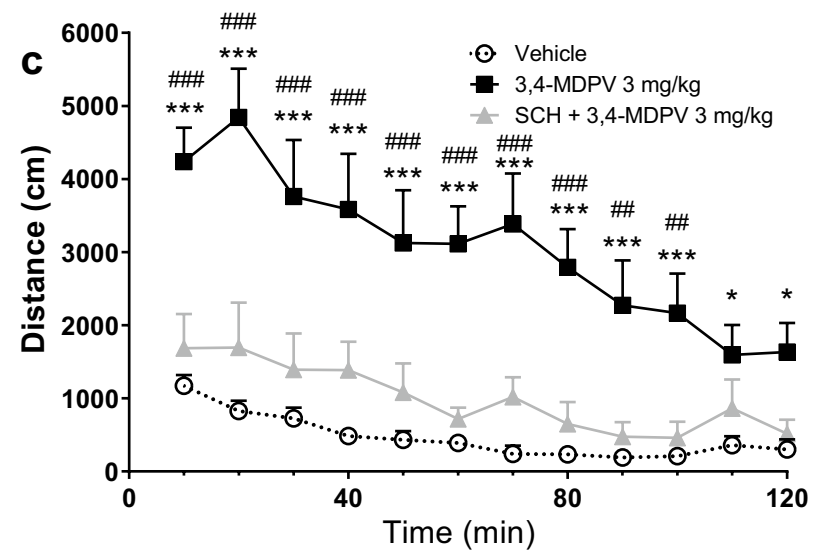

\section{Distance}

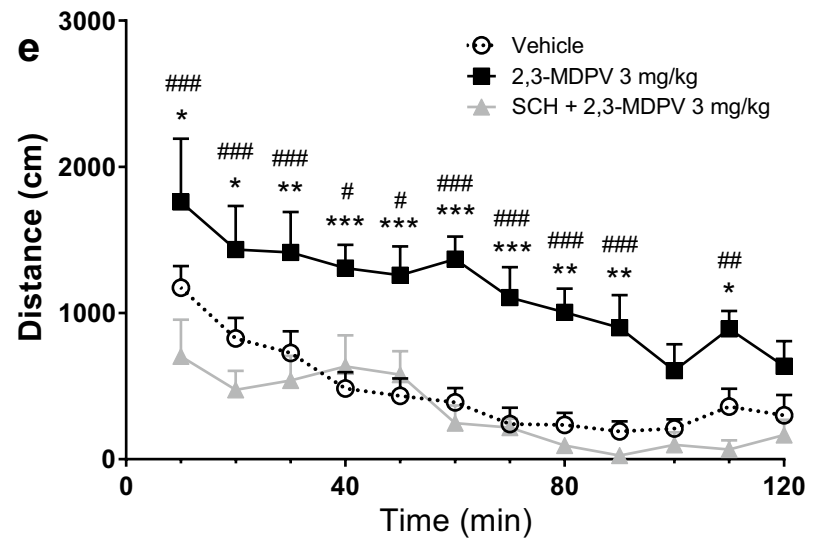

Fig. 4 Effects of SCH 23390 (SCH; $0.06 \mathrm{mg} / \mathrm{kg}$ ) pre-treatment on the locomotor stimulation elicited by pyrovalerone (Pyro; $3 \mathrm{mg} / \mathrm{kg})(\mathbf{a}$, b), 3,4-MDPV (3 mg/kg) (c, d) and 2,3-MDPV (3 mg/kg) (e, f). Panels a, c, e depict average horizontal activities in 10-min bins, while

indicates its stronger psychostimulant effect in comparison with 2,3-MDPV and pyrovalerone (Fig. 6b). The results of behavioral studies are in line with those of the microdialysis
Distance covered (120 min)

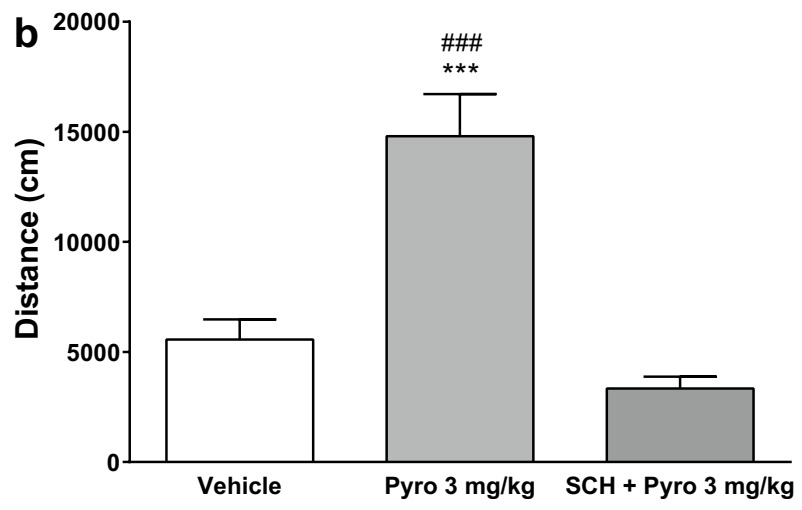

Distance covered (120 min)

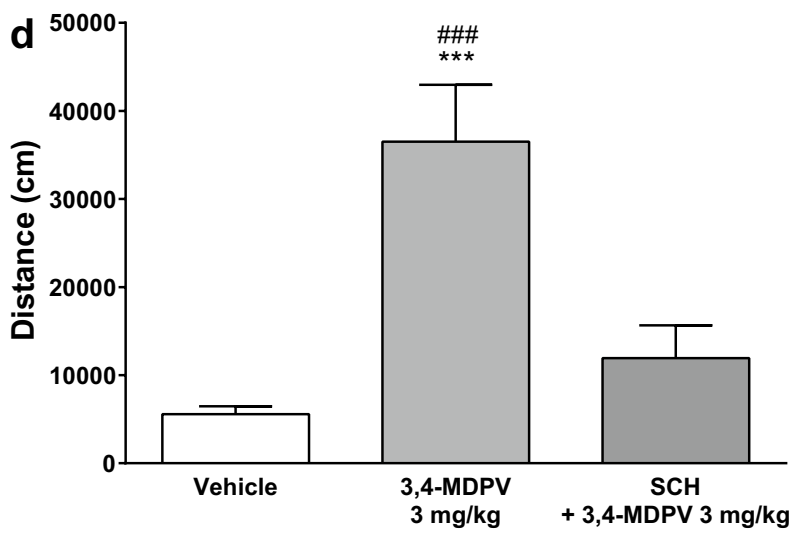

Distance covered (120 $\mathrm{min})$

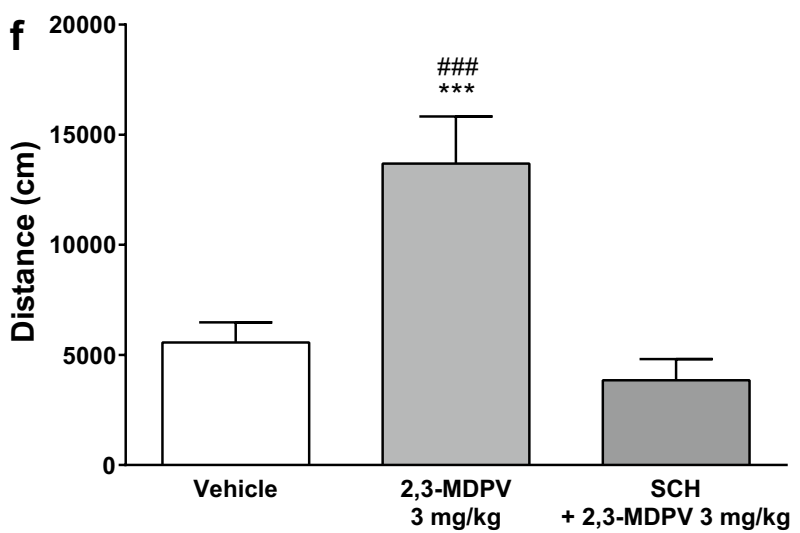

panels b, d, f depict total distance traveled during $120 \mathrm{~min}$. Data presented as mean \pm standard error of the mean (SEM) $(n=8-11)$. $* * * p<0.001 ; \quad * * p<0.01 ; \quad * p<0.05 \quad$ vs. control; ${ }^{*}{ }^{*} p<0.001$; ${ }^{\# \#} p<0.01 ;{ }^{*} p<0.05$ vs. SCH 23390 pre-treated group

experiments demonstrating that the increase of extracellular DA levels, expressed as the AUC for $180 \mathrm{~min}$, elicited by 3,4-MDPV is significantly more pronounced than these 
induced by 2,3-MDPV and pyrovalerone at $10 \mathrm{mg} / \mathrm{kg}$, and more pronounced than the effect of pyrovalerone used at the $3 \mathrm{mg} / \mathrm{kg}$ dose (Fig. $6 \mathrm{c}$ ). The observation that both the cumulative locomotor stimulation and increase of extracellular DA levels in the mouse striatum are significantly higher for 3,4-MDPV than for the other two tested pyrovalerones could be explained by a more long-lasting action of this compound. In fact, in animals treated with the $3 \mathrm{mg} / \mathrm{kg}$ dose constant, significant locomotor stimulation lasted for the full 120 min of recording after 3,4-MDPV administration, while in the case of 2,3-MDPV and pyrovalerone for $90 \mathrm{~min}$ and 70 min, respectively. These observations are reflected in the microdialysis study in which significantly elevated extracellular DA levels after 3,4-MDPV at the higher dose $(10 \mathrm{mg} /$ $\mathrm{kg}$ ) lasted for $40 \mathrm{~min}$ and 100 min longer, compared to 2,3MDPV and pyrovalerone, respectively. Our results are in line with previous findings demonstrating that psychostimulant effects of 3,4-MDPV are long-lasting. This can be seen in molecular studies, as the blockade of DA re-uptake was more persistent after 3,4-MDPV than in the case of cocaine, a model stimulant [29], and in animal models, where locomotor stimulation induced by 3,4-MDPV had a longer duration compared to cocaine and methamphetamine [17].

The present study shows that 3,4-MDPV, 2,3-MDPV and pyrovalerone are able to elicit stimulation of serotoninergic neurotransmission in vivo; this is consistent with our previous findings demonstrating a significant increase of extracellular 5-HT levels in the mouse striatum after treatment with three $\alpha$-pyrrolidinophenones structurally similar to 3,4MDPV, namely $\alpha$-PVP, PV8 and PV9 [36]. This observation can be explained by a functional cross-talk between dopaminergic and serotoninergic neurotransmission as described by Larsen et al. [38], and further supported by the fact that methamphetamine, another compound with great DAT selectivity over SERT in vitro, is also capable of increasing extracellular 5-HT level in vivo [39]. Interestingly, at the high tested dose the AUC for extracellular 5-HT levels was significantly higher after treatment with 2,3-MDPV compared to 3,4-MDPV. Furthermore, during 80-120 min postinjection 5-HT levels were markedly higher in mice treated with $3 \mathrm{mg} / \mathrm{kg}$ of 2,3-MDPV than in animals injected with the same dose of 3,4-MDPV (Fig. 6d, f). The observed difference in the psychostimulant activity between 3,4-MDPV and 2,3-MDPV could be explained by both the difference in their ability to inhibit DAT in vivo, duration of this action and distinct effects on the serotoninergic neurotransmission, as seen in microdialysis experiments. At present there are no data available on the affinity of 2,3-MDPV and its ability to inhibit DAT and SERT. Therefore, it is impossible to determine whether the difference in the potency of 3,4-MDPV and 2,3-MDPV to increase extracellular DA levels in vivo results from different potencies at their pharmacological target or is determined by other factors, as for example, distinct pharmacokinetic properties affecting blood-brain barrier permeability. The latter hypothesis seems reasonable, since in our previous work [36] we demonstrated that $\alpha$-PVP at $10 \mathrm{mg} / \mathrm{kg}$ produced significantly greater increase of horizontal locomotor activity and evoked more pronounced increase of extracellular DA levels in the mouse striatum than its derivative with an elongated $\alpha$-side chain, PV8 $(10 \mathrm{mg} / \mathrm{kg})$, while both compounds have similar affinities and potencies to inhibit DAT and SERT based on their in vitro evaluation using binding and uptake assays [33]. Similarly, we report a significantly higher ability of 3,4-MDPV to increase horizontal locomotor activity and extracellular DA levels in the mouse striatum than pyrovalerone, while both compounds had been reported to have similar $\mathrm{IC}_{50}$ for blocking DAT (0.05 $\mu \mathrm{M}$ for 3,4-MDPV and $0.07 \mu \mathrm{M}$ for pyrovalerone), and pyrovalerone was found to have DAT/SERT inhibition ratio 1.7 higher than 3,4-MDPV [2]. Additionally, we demonstrate that 2,3-MDPV is endowed with more pronounced serotoninergic effect than 3,4-MDPV. This observation is relevant because it is known that the ability to enhance 5-HT neurotransmission is negatively correlated with the psychostimulant potency, and shifts the drug's properties into a more empathogenic, MDMA-like type. During 80-120 min post-injection DA levels in groups treated with $3 \mathrm{mg} / \mathrm{kg}$ of 3,4-MDPV and 2,3-MDPV did not differ significantly, while the group treated with 2,3-MDPV had significantly higher 5-HT levels, which reached its peak at $100 \mathrm{~min}$ postinjection (Fig. 6e, f). This finding may serve as a possible explanation for the difference in the duration of increased horizontal locomotor activity. In the case of 3,4-MDPV it remained significant through $120 \mathrm{~min}$ of experiment, while in the case of 2,3-MDPV a decrease of the locomotor activity to the insignificant levels was observed after $90 \mathrm{~min}$ postinjection, which paralleled the increase of extracellular 5-HT levels in the striatum, supporting the inhibitory effects of serotoninergic neurotransmission on the spontaneous locomotor activity. Further research at the molecular level is needed to decisively explain the cause of the difference in pharmacological properties of 2,3-MDPV and 3,4-MDPV.

It appears likely that the increase of extracellular 5-HT levels in the mouse striatum is a secondary phenomenon to changes in DA concentration. Thus, in animals treated with 2,3-MDPV and pyrovalerone, peaks of 5-HT concentrations were detected after the maximum levels of DA, and at the same time point after $3,4-\mathrm{MDPV}$ at $10 \mathrm{mg} / \mathrm{kg}$. In all cases, apart from 3,4-MDPV at $10 \mathrm{mg} / \mathrm{kg}$, where both monoamines were significantly elevated through the entire course of analysis, increased 5-HT levels are detected for a longer duration than these of DA. This observation further supports the secondary character of DA-5-HT cross-talk, as increased 5-HT levels were observed even when concentration of the compounds dropped below the threshold for DAT inhibition. 
DA

\section{Pyrovalerone}

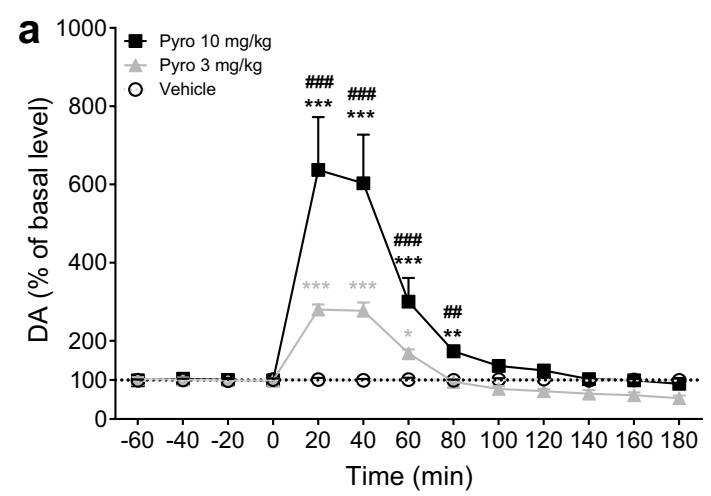

3,4-MDPV

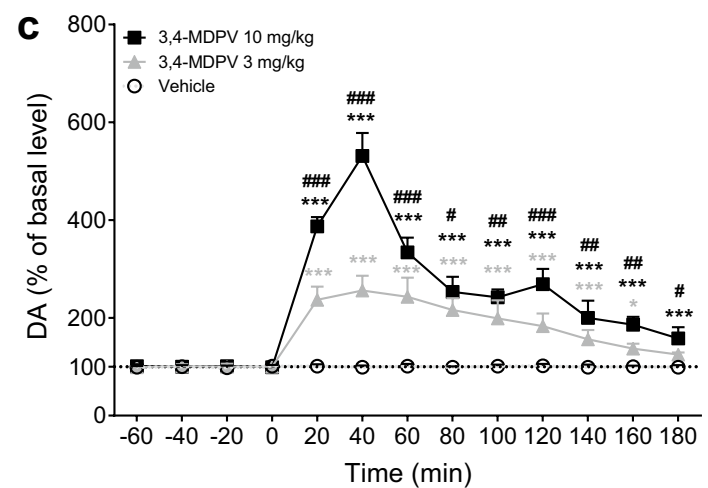

2,3-MDPV
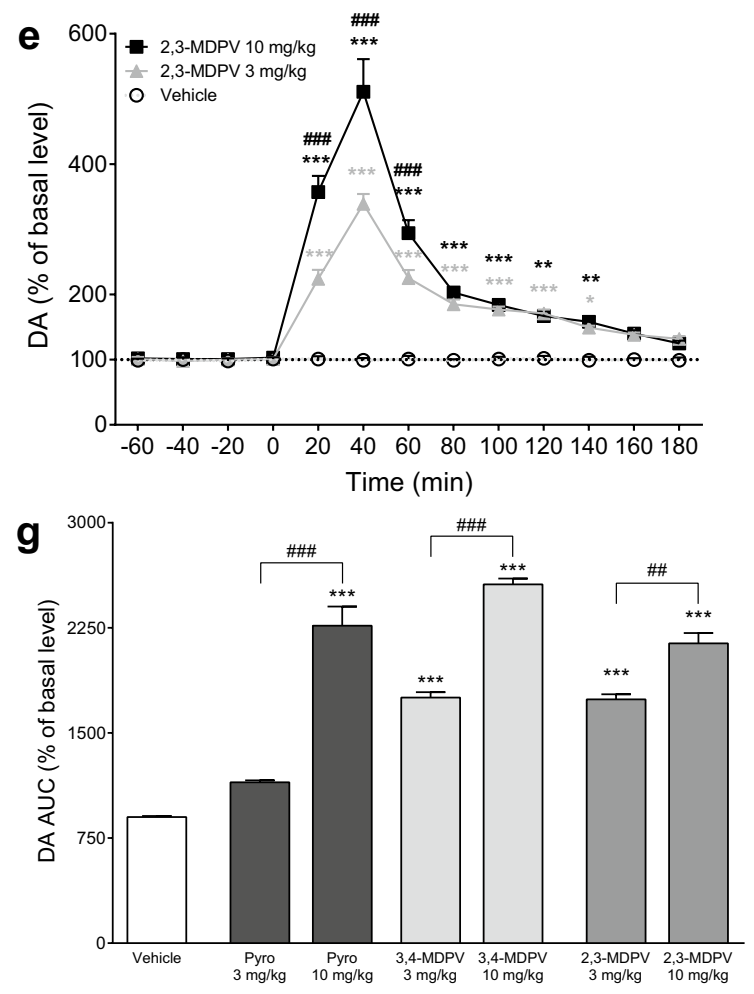

\section{5-HT}

Pyrovalerone

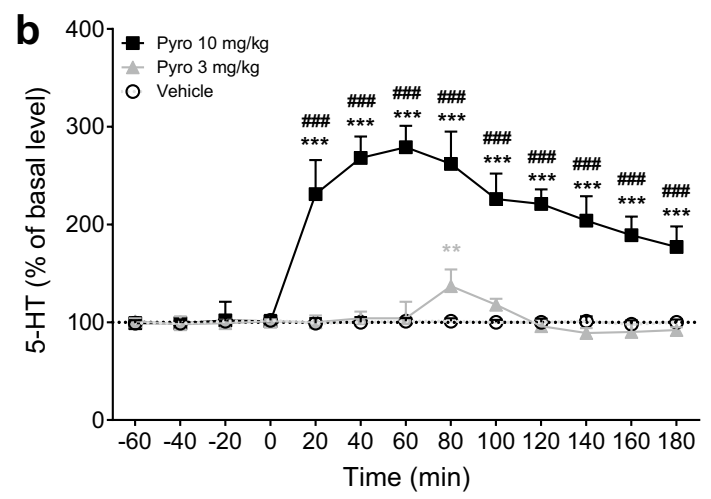

\section{3,4-MDPV}

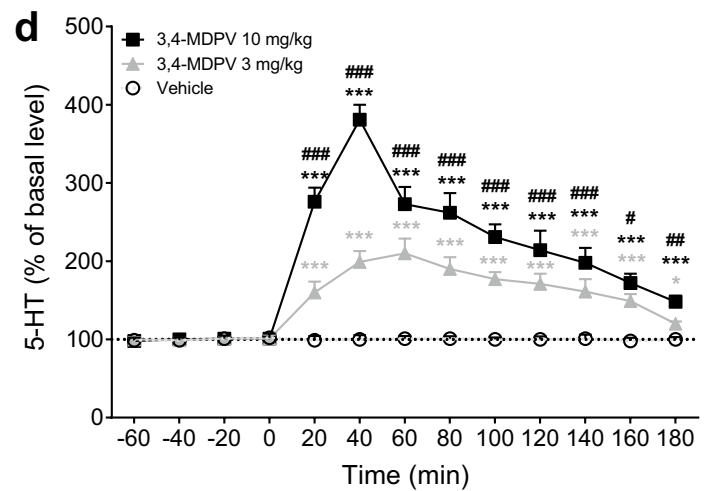

\section{2,3-MDPV}
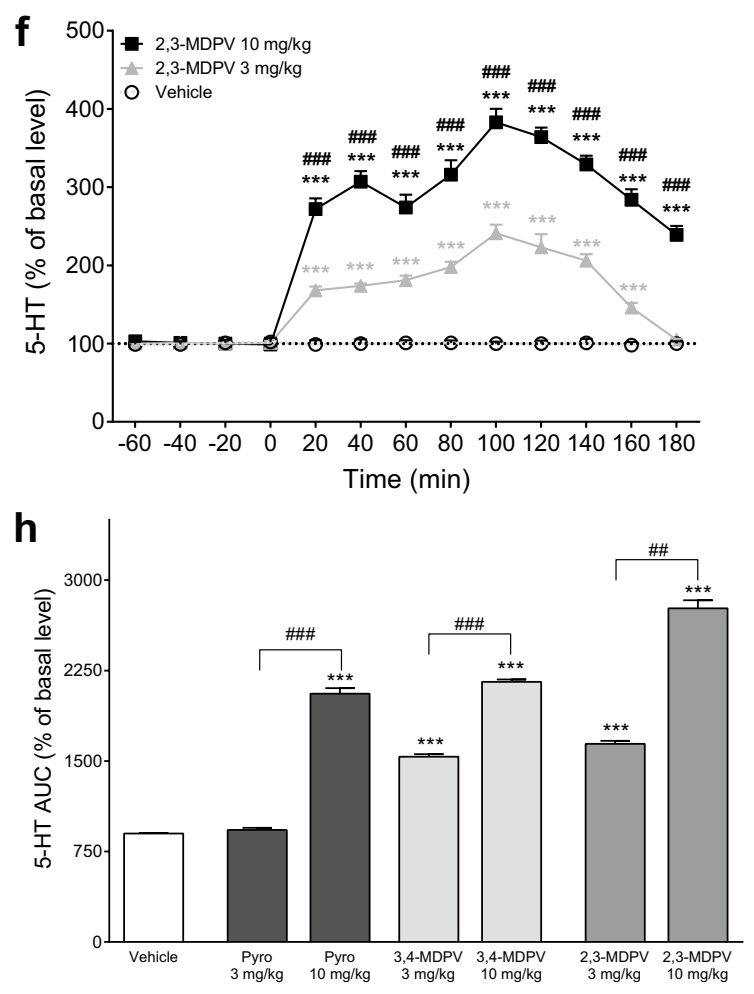
४Fig. 5 Effects of pyrovalerone (Pyro; 3, $10 \mathrm{mg} / \mathrm{kg}$ ), 3,4-MDPV (3, $10 \mathrm{mg} / \mathrm{kg})$ and 2,3-MDPV $(3,10 \mathrm{mg} / \mathrm{kg})$ on the extracellular level of dopamine (DA) (a, c, e) and serotonin (5-HT) $(\mathbf{b}, \mathbf{d}, \mathbf{f})$ in the mouse striatum shown as a time course or as an area under the curve, AUC $(\mathbf{g}, \mathbf{h})$. Data presented as mean \pm SEM $(\mathrm{n}=6-7)$. *** $p<0.001$; ${ }^{* *} p<0.01 ; * p<0.05$ vs. control group; ${ }^{\# \#} p<0.001 ;{ }^{\# \#} p<0.01$; ${ }^{\#} p<0.053 \mathrm{mg} / \mathrm{kg}$ vs. $10 \mathrm{mg} / \mathrm{kg}$

The psychostimulant effects of pyrovalerone, 3,4MDPV and 2,3-MDPV are mediated by stimulation of $\mathrm{D}_{1}$-DA receptors; this was demonstrated by the full abolition of the increase of horizontal locomotor activity elicited by the tested drugs $(3 \mathrm{mg} / \mathrm{kg})$ by the selective $\mathrm{D}_{1}$ antagonist, SCH $23390(0.06 \mathrm{mg} / \mathrm{kg})$. These observations are in line with expectations based on results from previous studies, where behavioral effects of other synthetic cathinones (mephedrone [27], methcathinone and 3-fluoromethcathinone [40], and $\alpha$-pyrrolidinophenones, such as 3,4-MDPV [21] and $\alpha$-PVP [36]) were examined. The dose of $0.06 \mathrm{mg} / \mathrm{kg} \mathrm{SCH} 23390$ was based on our previous experience, where it was reported not to decrease by itself the basal locomotor activity of C57BL/6J mice [40], and fits in the broad range of doses used in experiments on rodents, from $0.03 \mathrm{mg} / \mathrm{kg}$ [21] to $0.5 \mathrm{mg} / \mathrm{kg}$ [27].

To our knowledge, this is the first study to compare the behavioral and neurochemical effects of 3,4-MDPV and 2,3-MDPV, along with pyrovalerone. Despite the fact that $3,4-\mathrm{MDPV}$ is considered as the precursor and model drug of $\alpha$-pyrrolidinophenones, there is a very limited number of studies comparing its effects to other members of the group, and these mainly concern $\alpha$-PVP $[10,18,21]$. However, results of these studies are not uniform. For instance, Giannotti et al. [18] report that 3,4-MDPV has a stronger action than $\alpha$-PVP on the spontaneous and forced locomotor activities in mice across all tested doses, which can be explained by the higher potency of 3,4-MDPV at inhibiting DAT [21]. Similarly, in the quoted study the locomotor stimulation produced by 3,4-MDPV was greater than those elicited by $\alpha$-PVP, $\alpha$-PBP and $\alpha$-PPP [21], which is paralleled with the differences of the listed compounds in their potency to inhibit DAT. These results correspond to our present findings, where 3,4-MDPV was a more potent psychostimulant than 2,3-MDPV and pyrovalerone, indicated by the fact that it elicited the most pronounced increase of extracellular DA levels in the striatum. Additionally, our previous study examining the locomotor response of mice recorded a visible increase of horizontal locomotor activity only during 90 min post-injection following a dose of $3 \mathrm{mg} / \mathrm{kg} \alpha$-PVP [36], which is shorter than that observed for the same dose of 3,4-MDPV in the present study (120 min). Taken together, it seems that the high popularity and prevalence of 3,4-MDPV within the $\alpha$-pyrrolidinophenones group might be attributed to its very potent pharmacological action. However, 3,4-MDPV and $\alpha$-PVP demonstrated similar effects and duration of action on locomotor response in rats, and peak effects occurred after the same dose of both compounds [10].

\section{Conclusions}

The current study shows that 2,3-MDPV, the positional isomer of 3,4-MDPV, and pyrovalerone, are endowed with psychostimulant properties, indicated by the increase of the spontaneous locomotor activity in mice and the elevation in the extracellular level of DA in the mouse striatum. As in the case of 3,4-MDPV and other synthetic cathinones, the 2,3-MDPVand pyrovalerone-induced locomotor activity is blocked by the selective $\mathrm{D}_{1}$ antagonist $\mathrm{SCH} 23390$, indicating that it is mediated by enhanced dopaminergic neurotransmission via $\mathrm{D}_{1}$-DA receptors. The psychostimulant potency of 2,3-MDPV is significantly lower than of its parent compound 3,4-MDPV, but at a similar level to pyrovalerone, in which the 3,4-methylenedioxy group is substituted with the 4-methyl- group. This observation highlights that the methylenedioxy group and its position within the phenyl ring plays a crucial role in the dopaminergic potency of $\alpha$-pyrrolidinophenones, besides the length of $\alpha$-side chain, which was previously reported to be the major factor contributing to the potency of $\alpha$-pyrrolidinophenones both in vitro and in animal models $[35,36]$. Additionally, the current study demonstrates that in contrast to the similar potency to inhibit DA uptake [2], 3,4-MDPV and pyrovalerone markedly differ in their potency to increase extracellular DA levels in the mouse striatum and to increase spontaneous locomotor activity. Furthermore, the increase of extracellular 5-HT levels in the mouse striatum elicited by 3,4-MDPV and its analogs despite very high DAT/SERT inhibition ratio and negligible affinity toward SERT in in vitro assays [2,33], supports the important role of DA-5-HT cross-talk in vivo. These observations point to the importance of in vivo studies, which are indispensable in the assessment of pharmacological properties of drugs of abuse as, in addition to pharmacodynamics, they cover pharmacokinetics which can be overseen when drugs are screened only using in vitro binding/uptake assays. 

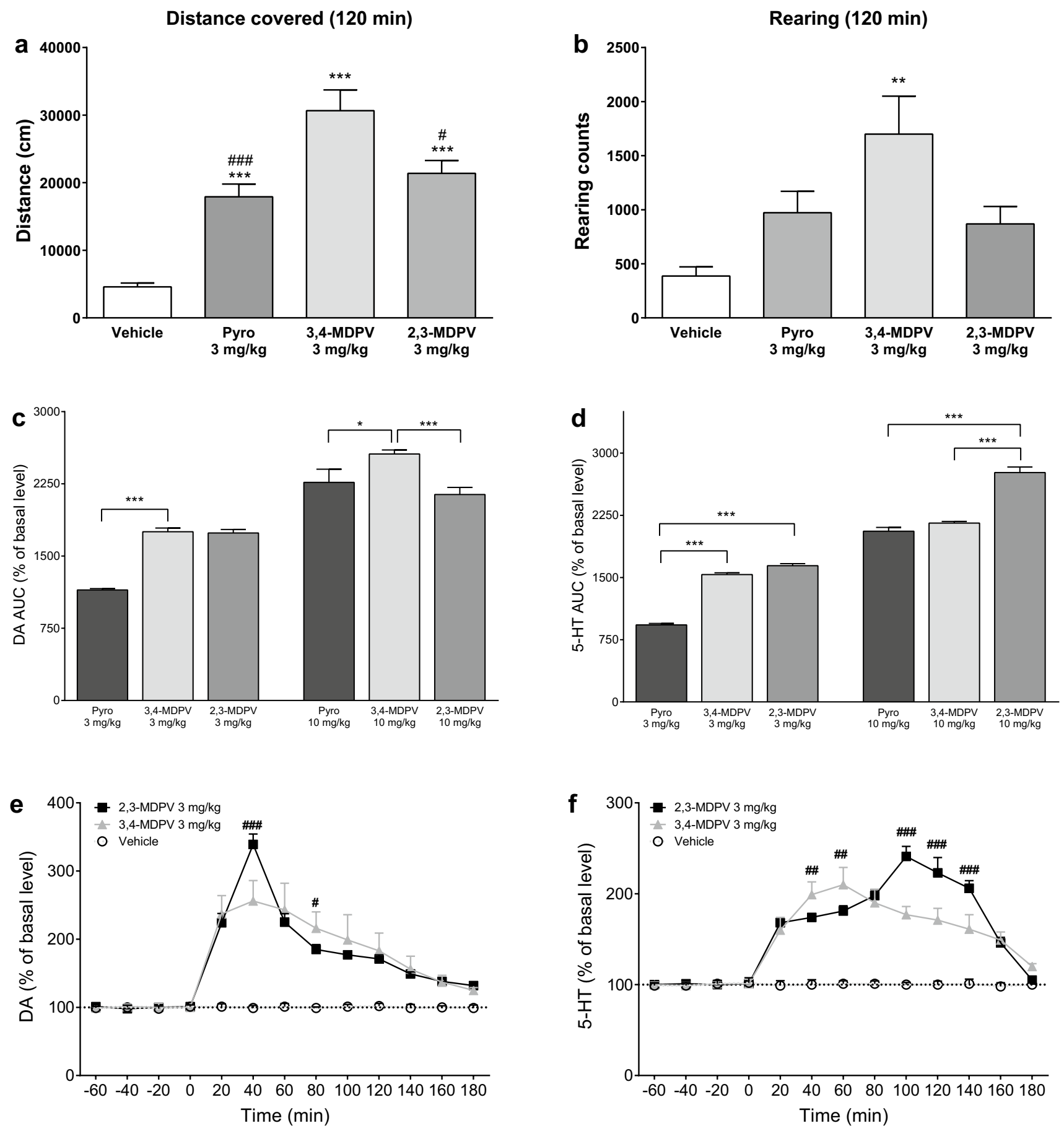

Fig. 6 Comparison of effects produced in mice by pyrovalerone (Pyro; 3, $10 \mathrm{mg} / \mathrm{kg}$ ), 3,4-MDPV (3, $10 \mathrm{mg} / \mathrm{kg})$ and 2,3-MDPV (3, $10 \mathrm{mg} / \mathrm{kg}$ ). a Total distance traveled during $120 \mathrm{~min}$. b Total rearing counts during $120 \mathrm{~min}$. Changes in the extracellular levels of dopamine (DA) or serotonin (5-HT) in striata of mice expressed as

AUC (c, d, respectively) and time course (e, f, respectively). Data presented as mean \pm standard error of the mean (SEM) $(n=6-8)$. $* * * p<0.001 ; * * p<0.01 ; * p<0.05$ vs. control, unless otherwise marked; ${ }^{\# \#} p<0.001 ;{ }^{\# \#} p<0.01 ;{ }^{\#} p<0.05$ vs. group treated with $3,4-$ MDPV $(3 \mathrm{mg} / \mathrm{kg})$ 
Acknowledgements Supported by the National Science Centre, Kraków, Poland (Grant no 2014/13/B/NZ7/02237).

\section{Compliance with ethical standards}

Conflict of interest The authors have no financial or other relationships that could lead to a conflict of interest.

Ethical approval The use of adult male C57BL/6J inbred mice for the experiments was approved by the Local Ethical Commissions for Experimentations on Animals in Łódź and Kraków. This article does not contain any studies with human participants.

Open Access This article is licensed under a Creative Commons Attribution 4.0 International License, which permits use, sharing, adaptation, distribution and reproduction in any medium or format, as long as you give appropriate credit to the original author(s) and the source, provide a link to the Creative Commons licence, and indicate if changes were made. The images or other third party material in this article are included in the article's Creative Commons licence, unless indicated otherwise in a credit line to the material. If material is not included in the article's Creative Commons licence and your intended use is not permitted by statutory regulation or exceeds the permitted use, you will need to obtain permission directly from the copyright holder. To view a copy of this licence, visit http://creativecommons.org/licenses/by/4.0/.

\section{References}

1. EMCDDA (2019) European drug report 2019: trends and developments. https://www.emcdda.europa.eu/system/files/publicatio ns/11364/20191724_TDAT19001ENN_PDF.pdf. Accessed 27 Aug 2019.

2. Rickli A, Hoener MC, Liechti ME (2015) Monoamine transporter and receptor interaction profiles of novel psychoactive substances: Para-halogenated amphetamines and pyrovalerone cathinones. Eur Neuropsychopharmacol 25(3):365-376. https ://doi.org/10.1016/j.euroneuro.2014.12.012

3. Simmler LD, Buser TA, Donzelli M, Schramm Y, Dieu LH, Huwyler J, Chaboz S, Hoener MC, Liechti ME (2013) Pharmacological characterization of designer cathinones in vitro. Br J Pharmacol 168(2):458-470. https://doi.org/10.1111/j.1476-5381.2012.02145 .x

4. Zawilska JB, Wojcieszak J (2013) Designer cathinones-an emerging class of novel recreational drugs. Forensic Sci Int 231(1-3):42-53. https://doi.org/10.1016/j.forsciint.2013.04.015

5. Karila L, Lafaye G, Scocard A, Cottencin O, Benyamina A (2018) MDPV and $\alpha$-PVP use in humans: the twisted sisters. Neuropharmacology 134(Pt A):65-72. https://doi.org/10.1016/j.neuropharm .2017.10.007

6. Baumann MH, Partilla JS, Lehner KR, Thorndike EB, Hoffman AF, Holy M, Rothman RB, Goldberg SR, Lupica CR, Sitte HH, Brandt SD, Tella SR, Cozzi NV, Schindler CW (2013) Powerful cocaine-like actions of 3,4-methylenedioxypyrovalerone (MDPV), a principal constituent of psychoactive 'bath salts' products. Neuropsychopharmacology 38(4):552-562. https://doi.org/10.1038/ npp.2012.204

7. Cameron KN, Kolanos R, Solis E Jr, Glennon RA, De Felice LJ (2013) Bath salts components mephedrone and methylenedioxypyrovalerone (MDPV) act synergistically at the human dopamine transporter. Br J Pharmacol 168(7):1750-1757. https://doi. org/10.1111/bph.12061
8. Horsley RR, Lhotkova E, Hajkova K, Feriancikova B, Himl M, Kucharr M, Páleníček T (2018) Behavioural, pharmacokinetic, metabolic, and hyperthermic profile of 3,4-methylenedioxypyrovalerone (MDPV) in the Wistar rat. Front Psychiatry 9:144. https ://doi.org/10.3389/fpsyt.2018.00144

9. Schindler CW, Thorndike EB, Goldberg SR, Lehner KR, Cozzi NV, Brandt SD, Baumann MH (2016) Reinforcing and neurochemical effects of the "bath salts" constituents 3,4-methylenedioxypyrovalerone (MDPV) and 3,4-methylenedioxy- $N$-methylcathinone (methylone) in male rats. Psychopharmacology 233(10):1981-1990. https://doi.org/10.1007/s00213-015-4057-0

10. Aarde SM, Creehan KM, Vandewater SA, Dickerson TJ, Taffe MA (2015) In vivo potency and efficacy of the novel cathinone $\alpha$-pyrrolidinopentiophenone and 3,4-methylenedioxypyrovalerone: self-administration and locomotor stimulation in male rats. Psychopharmacology 232(16):3045-3055. https://doi. org/10.1007/s00213-015-3944-8

11. Aarde SM, Huang PK, Creehan KM, Dickerson TJ, Taffe MA (2013) The novel recreational drug 3,4-methylenedioxypyrovalerone (MDPV) is a potent psychomotor stimulant: self-administration and locomotor activity in rats. Neuropharmacology 71:130-140. https://doi.org/10.1016/j.neuropharm.2013.04.003

12. Allen SA, Tran LH, Oakes HV, Brown RW, Pond BB (2019) Dopaminergic effects of major bath salt constituents 3,4-methylenedioxypyrovalerone (MDPV), mephedrone, and methylone are enhanced following co-exposure. Neurotox Res 36(1):132-143. https://doi.org/10.1007/s12640-019-00020-2

13. Anizan S, Concheiro M, Lehner KR, Bukhari MO, Suzuki M, Rice KC, Baumann MH, Huestis MA (2016) Linear pharmacokinetics of 3,4-methylenedioxypyrovalerone (MDPV) and its metabolites in the rat: relationship to pharmacodynamic effects. Addict Biol 21(2):339-347. https://doi.org/10.1111/adb.12201

14. Atehortua-Martinez LA, Masniere C, Campolongo P, Chasseigneaux S, Callebert J, Zwergel C, Mai A, Laplanche JL, Chen H, Etheve-Quelquejeu M, Mégarbane B, Benturquia N (2019) Acute and chronic neurobehavioral effects of the designer drug and bath salt constituent 3,4-methylenedioxypyrovalerone in the rat. J Psychopharmacol 33(3):392-405. https://doi.org/10.1177/02698 81118822151

15. Berquist MD 2nd, Traxler HK, Mahler AM, Baker LE (2016) Sensitization to the locomotor stimulant effects of "bath salt" constituents, 4-methylmethcathinone (4-MMC) and 3,4-methylenedioxypyrovalerone (MDPV), in male Sprague-Dawley rats. Drug Alcohol Depend 164:128-134. https://doi.org/10.1016/j.druga lcdep.2016.05.001

16. Fantegrossi WE, Gannon BM, Zimmerman SM, Rice KC (2013) In vivo effects of abused 'bath salt' constituent 3,4-methylenedioxypyrovalerone (MDPV) in mice: drug discrimination, thermoregulation, and locomotor activity. Neuropsychopharmacology 38(4):563-573. https://doi.org/10.1038/npp.2012.233

17. Gatch MB, Taylor CM, Forster MJ (2013) Locomotor stimulant and discriminative stimulus effects of 'bath salt' cathinones. Behav Pharmacol 24(5-6):437-447. https://doi.org/10.1097/ FBP.0b013e328364166d

18. Giannotti G, Canazza I, Caffino L, Bilel S, Ossato A, Fumagalli F, Marti M (2017) The cathinones MDPV and $\alpha$-PVP elicit different behavioral and molecular effects following acute exposure. Neurotox Res 32(4):594-602. https://doi.org/10.1007/s1264 0-017-9769-y

19. Harvey EL, Burroughs RL, Baker LE (2017) Effects of D1 and D2 receptor antagonists on the discriminative stimulus effects of methylendioxypyrovalerone and mephedrone in male SpragueDawley rats trained to discriminate $d$-amphetamine. Behav Pharmacol 28(7):586-589. https://doi.org/10.1097/FBP.0000000000 000328 
20. Kohler RJ, Perrine SA, Baker LE (2018) Repeated exposure to 3,4-methylenedioxypyrovalerone and cocaine produces locomotor sensitization with minimal effects on brain monoamines. Neuropharmacology 134(Pt A):22-27. https://doi.org/10.1016/j.neuro pharm.2017.10.019

21. Marusich JA, Antonazzo KR, Wiley JL, Blough BE, Partilla JS, Baumann MH (2014) Pharmacology of novel synthetic stimulants structurally related to the "bath salts" constituent 3,4-methylenedioxypyrovalerone (MDPV). Neuropharmacology 87:206-213. https://doi.org/10.1016/j.neuropharm.2014.02.016

22. Marusich JA, Grant KR, Blough BE, Wiley JL (2012) Effects of synthetic cathinones contained in "bath salts" on motor behavior and a functional observational battery in mice. Neurotoxicology 33(5):1305-1313. https://doi.org/10.1016/j.neuro.2012.08.003

23. Nguyen JD, Aarde SM, Cole M, Vandewater SA, Grant Y, Taffe MA (2016) Locomotor stimulant and rewarding effects of inhaling methamphetamine, MDPV, and mephedrone via electronic cigarette-type technology. Neuropsychopharmacology 41(11):27592771. https://doi.org/10.1038/npp.2016.88

24. Oliver CF, Simmons SJ, Nayak SU, Smith GR, Reitz AB, Rawls SM (2018) Chemokines and 'bath salts': CXCR4 receptor antagonist reduces rewarding and locomotor-stimulant effects of the designer cathinone MDPV in rats. Drug Alcohol Depend 186:7579. https://doi.org/10.1016/j.drugalcdep.2018.01.013

25. Gannon BM, Russell LN, Modi MS, Rice KC, Fantegrossi WE (2017) Effects of orally self-administered bath salt constituent 3,4-methylenedioxypyrovalerone (MDPV) in mice. Drug Alcohol Depend 179:408-415. https://doi.org/10.1016/j.drugalcdep .2017.06.031

26. Bonano JS, Glennon RA, De Felice LJ, Banks ML, Negus SS (2014) Abuse-related and abuse-limiting effects of methcathinone and the synthetic "bath salts" cathinone analogs methylenedioxypyrovalerone (MDPV), methylone and mephedrone on intracranial self-stimulation in rats. Psychopharmacology 231(1):199-207. https://doi.org/10.1007/s00213-013-3223-5

27. Lisek R, Xu W, Yuvasheva E, Chiu YT, Reitz AB, Liu-Chen LY, Rawls SM (2012) Mephedrone ('bath salt') elicits conditioned place preference and dopamine-sensitive motor activation. Drug Alcohol Depend 126(1-2):257-262. https://doi.org/10.1016/j. drugalcdep.2012.04.021

28. Duart-Castells L, López-Arnau R, Buenrostro-Jáuregui M, Muñoz-Villegas P, Valverde O, Camarasa J, Pubill D, Escubedo E (2019) Neuroadaptive changes and behavioral effects after a sensitization regime of MDPV. Neuropharmacology 144:271-281. https://doi.org/10.1016/j.neuropharm.2018.10.005

29. López-Arnau R, Duart-Castells L, Aster B, Camarasa J, Escubedo E, Pubill D (2019) Effects of MDPV on dopamine transporter regulation in male rats. Comparison with cocaine. Psychopharmacology 236(3):925-938. https://doi.org/10.1007/s00213-018-5052-z

30. López-Arnau R, Luján MA, Duart-Castells L, Pubill D, Camarasa J, Valverde O, Escubedo E (2017) Exposure of adolescent mice to 3,4-methylenedioxypyrovalerone increases the psychostimulant, rewarding and reinforcing effects of cocaine in adulthood. Br J Pharmacol 174(10):1161-1173. https://doi.org/10.1111/ bph. 13771
31. Gannon BM, Williamson A, Suzuki M, Rice KC, Fantegrossi WE (2016) Stereoselective effects of abused "Bath Salt" constituent 3,4-methylenedioxypyrovalerone in mice: Drug discrimination, locomotor activity, and thermoregulation. J Pharmacol Exp Ther 356(3):615-623. https://doi.org/10.1124/jpet.115.229500

32. Kolanos R, Partilla JS, Baumann MH, Hutsell BA, Banks ML, Negus SS, Glennon RA (2015) Stereoselective actions of methylenedioxypyrovalerone (MDPV) to inhibit dopamine and norepinephrine transporters and facilitate intracranial self-stimulation in rats. ACS Chem Neurosci 6(5):771-777. https://doi.org/10.1021/ acschemneuro.5b00006

33. Eshleman AJ, Wolfrum KM, Reed JF, Kim SO, Swanson T, Johnson RA, Janowsky A (2017) Structure-activity relationships of substituted cathinones, with transporter binding, uptake and release. J Pharmacol Exp Ther 360:33-47. https://doi.org/10.1124/ jpet.116.236349

34. Gatch MB, Dolan SB, Forster MJ (2015) Comparative behavioral pharmacology of three pyrrolidine-containing synthetic cathinone derivatives. J Pharmacol Exp Ther 354(2):103-110. https://doi. org/10.1124/jpet.115.223586

35. Kolanos R, Sakloth F, Jain AD, Partilla JS, Baumann MH, Glennon RA (2015) Structural modification of the designer stimulant $\alpha$-pyrrolidinovalerophenone ( $\alpha$-PVP) influences potency at dopamine transporters. ACS Chem Neurosci 6(10):1726-1731. https ://doi.org/10.1021/acschemneuro.5b00160

36. Wojcieszak J, Andrzejczak D, Wojtas A, Gołembiowska K, Zawilska JB (2018) Effects of the new generation $\alpha$-pyrrolidinophenones on spontaneous locomotor activities in mice, and on extracellular dopamine and serotonin levels in the mouse striatum. Forensic Toxicol 36(2):334-350. https://doi. org/10.1007/s11419-018-0409-x

37. Paxinos G, Franklin K (2008) The mouse brain in stereotaxic coordinates, 3rd edn. Academic, Cambridge

38. Larsen MB, Sonders MS, Mortensen OV, Larson GA, Zahniser NR, Amara SG (2011) Dopamine transport by the serotonin transporter: a mechanistically distinct mode of substrate translocation. J Neurosci 31(17):6605-6615. https://doi.org/10.1523/JNEUR OSCI.0576-11.2011

39. Matsumoto T, Maeno Y, Kato H, Seko-Nakamura Y, MonmaOhtaki J, Ishiba A, Nagao M, Aoki Y (2014) 5-hydroxytryptamine- and dopamine-releasing effects of ring-substituted amphetamines on rat brain: a comparative study using in vivo microdialysis. Eur Neuropsychopharmacol 24(8):1362-1370. https://doi.org/10.1016/j.euroneuro.2014.04.009

40. Wojcieszak J, Andrzejczak D, Wojtas A, Gołembiowska K, Zawilska JB (2019) Methcathinone and 3-fluoromethcathinone stimulate spontaneous horizontal locomotor activity in mice and elevate extracellular dopamine and serotonin levels in the mouse striatum. Neurotox Res 35(3):594-605. https://doi.org/10.1007/ s12640-018-9973-4

Publisher's Note Springer Nature remains neutral with regard to jurisdictional claims in published maps and institutional affiliations. 